\title{
Age-Related Declines in Prefrontal Cortical Expression of Metabotropic Glutamate Receptors that Support Working Memory
}

\author{
Caesar M. Hernandez, ${ }^{1}$ Joseph A. McQuail,, ${ }^{1}$ Miranda R. Schwabe, ${ }^{1}{ }^{\circledR S a r a}$ N. Burke, ${ }^{1}$ Barry Setlow, ${ }^{1,2}$ \\ and Jennifer L. Bizon ${ }^{1,2}$
}

DOI:http://dx.doi.org/10.1523/ENEURO.0164-18.2018

${ }^{1}$ Department of Neuroscience, University of Florida, Gainesville, FL 32610 and ${ }^{2}$ Department of Psychiatry, University of Florida, Gainesville, FL 32610

\begin{abstract}
Glutamate signaling is essential for the persistent neural activity in prefrontal cortex (PFC) that enables working memory. Metabotropic glutamate receptors (mGluRs) are a diverse class of proteins that modulate excitatory neurotransmission via both presynaptic regulation of extracellular glutamate levels and postsynaptic modulation of ion channels on dendritic spines. This receptor class is of significant therapeutic interest for treatment of cognitive disorders associated with glutamate dysregulation. Working memory impairment and cortical hypoexcitability are both associated with advanced aging. Whether aging modifies PFC mGluR expression, and the extent to which any such alterations are regionally or subtype specific, however, is unknown. Moreover, it is unclear whether specific mGluRs in PFC are critical for working memory, and thus, whether altered mGluR expression in aging or disease is sufficient to play a causative role in working memory decline. Experiments in the current study first evaluated the effects of age on medial PFC (mPFC) mGluR expression using biochemical and molecular approaches in rats. Of the eight mGluRs examined, only mGluR5, mGluR3, and mGluR4 were significantly reduced in the aged PFC. The reductions in mGluR3 and mGluR5 (but not mGluR4) were observed in both mRNA and protein and were selectively localized to the prelimbic (PrL), but not infralimbic (IL), subregion of mPFC. Finally, pharmacological blockade of mGluR5 or mGluR2/3 using selective antagonists directed to PrL significantly impaired working memory without influencing non-mnemonic aspects of task performance. Together, these data implicate attenuated expression of PFC mGluR5 and mGluR3 in the impaired working memory associated with advanced ages.
\end{abstract}

Key words: aging; metabotropic glutamate receptor; prefrontal cortex; prelimbic cortex; rat; working memory

\section{Significance Statement}

Working memory is impaired in several neuropsychiatric disorders and advanced aging. Glutamate is essential for persistent cellular activity in the prefrontal cortex (PFC) theorized to maintain working memory. Metabotropic glutamate receptors (mGluRs) are well positioned to coordinate glutamate signaling at PFC synapses; however, studies to date have not yet systematically investigated the contributions of mGluR subtypes to normal working memory and PFC aging. This study shows that aging is accompanied by loss of PFC mGluR2/3 and mGluR5 mRNA and protein and that pharmacological inhibition of these mGluR subtypes is sufficient to impair working memory. These findings suggest that mGluRs have a normal role in working memory and could serve as a target for treatment of cognitive disorders characterized by PFC dysfunction.

Received April 26, 2018; accepted June 7, 2018; First published June 15, 2018.

The authors declare no competing financial interests.
Author contributions: C.M.H., J.A.M., S.N.B., and J.L.B. designed research; C.M.H., J.A.M., and M.R.S. performed research; C.M.H., J.A.M., B.S., and J.L.B. analyzed data; C.M.H., J.A.M., B.S., and J.L.B. wrote the paper. 


\section{Introduction}

Working memory involves the temporary representation of information to guide goal-directed behavior and is a foundational aspect of higher order cognition that is ascribed to the prefrontal cortex (PFC; Baddeley, 1986; Goldman-Rakic, 1996). The neural basis of working memory is theorized to depend on persistent firing of PFC pyramidal neurons that requires recurrent excitation of ionotropic glutamate receptors (Goldman-Rakic, 1995; Wang et al., 2013). Comparatively less work, however, has considered a role for slower, modulatory signaling achieved via metabotropic glutamate receptors (mGluRs). The mGluRs belong to the class $C$ family of $G$ proteincoupled receptors (Tanabe et al., 1992; Bjarnadóttir et al., 2006) and are subdivided into three groups on the basis of their sequence homology and downstream signaling mechanisms (Bishop and Ellingrod, 2007). In dendritic spines, Group I and some Group II mGluRs regulate ion channel activity and intracellular $\mathrm{Ca}^{2+}$ release to influence neural excitability (Mannaioni et al., 2001; Tyszkiewicz et al., 2004; Hagenston et al., 2008; Niswender and Conn, 2010; Arnsten et al., 2012; Jin et al., 2017). Also essential regulators of extracellular glutamate, Group II and III mGluRs localize to excitatory terminals and glial processes where they modulate the synaptic release of glutamate (Tanabe et al., 1993; Okamoto et al., 1994; Sansig et al., 2001) and glutamate uptake (Aronica et al., 2003; Corti et al., 2007), respectively.

The mGluRs are of significant therapeutic interest for treating PFC glutamate dysregulation and working memory dysfunction in several neuropsychiatric diseases, including schizophrenia and major depressive disorder. It is unclear whether deficient mGluR expression is causally linked to the working memory impairments observed in these conditions, however, as some studies show reductions in PFC Group I and Group II mGluR expression in schizophrenia and depression (Ghose et al., 2009; Corti et al., 2011; Deschwanden et al., 2011; McOmish et al., 2016), whereas others do not (Crook et al., 2002; Frank et al., 2011; Matosin et al., 2013). Aside from their potential roles in cognitive dysfunction in disease states, a secondary observation from this literature is that expression of at least some mGluR subtypes appears to decline across the lifespan, independent of the manifestation of psychiatric conditions (Crook et al., 2002; Corti et al.,

This work was supported by the NIH Grant R01AG029421 and the McKnight Brain Research Foundation (J.L.B.), a McKnight Predoctoral Fellowship and a Pat Tillman Foundation scholarship (C.M.H.), the NIH Grant F32AG051371 (J.A.M.), and a University of Florida University Scholars Program Award (M.R.S.).

Acknowledgements: We thank Vicky S. Kelly, Shannon C. Wall, Matthew M. Bruner, Chase C. Labiste, Tyler W. Ten Eyck, and Alexa-Rae Wheeler for technical assistance.

Correspondence should be addressed to Jennifer L. Bizon, Ph.D., Department of Neuroscience, University of Florida, PO Box 100244, Gainesville, FL 32610-0244, E-mail: bizonj@ufl.edu.

DOI:http://dx.doi.org/10.1523/ENEURO.0164-18.2018

Copyright @ 2018 Hernandez et al.

This is an open-access article distributed under the terms of the Creative Commons Attribution 4.0 International license, which permits unrestricted use, distribution and reproduction in any medium provided that the original work is properly attributed.
2011; Frank et al., 2011). These initial observations suggest that attenuated mGluR expression with age may be a contributing factor to the precipitous working memory decline that often accompanies aging (Oscar-Berman and Bonner, 1985; Dunnett et al., 1988; Rapp and Amaral, 1989; Bachevalier et al., 1991; Lamar and Resnick, 2004; Beas et al., 2013; McQuail et al., 2016; Hernandez et al., 2017). Importantly, however, the effects of age on mGluR expression have only been examined in retrospective studies in populations with neuropsychiatric disease.

The overarching goal of the current study was to comprehensively evaluate mGluR expression in aged rat medial PFC (mPFC), the rodent homolog of primate dorsolateral PFC. The findings indicate that mGluR3 and mGluR5 expression decline specifically in the prelimbic (PrL) but not infralimbic (IL) subregion of mPFC. All other mGluRs were largely stable with age in both PFC subregions. Importantly, blockade of either mGluR2/3 or mGluR5 in the PrL reliably impaired working memory performance in young rats. Together, these data implicate selective reductions in PrL mGluR expression in ageassociated working memory decline and suggest that targeting these receptors may have potential for improving working memory in aging and other disorders.

\section{Materials and Methods}

\section{Subjects}

Young adult (four months, $n=38$ ) and aged (22 months, $n=30$ ) male Fischer 344 (F344) rats were obtained from the National Institute on Aging's Aging Rodent Colony maintained by Charles River Laboratories. All animals were housed in the Association for Assessment and Accreditation of Laboratory Animal Care Internationalaccredited vivarium facility in the McKnight Brain Institute Building at the University of Florida. The facility was maintained at a consistent temperature of $25^{\circ} \mathrm{C}$ with a $12 / 12 \mathrm{~h}$ light/dark cycle (lights on at 7 A.M.) with free access to food and water except as otherwise noted. All animal procedures were reviewed and approved by the University of Florida Institutional Animal Care and Use Committee and followed National Institutes of Health guidelines. In experiment 1, a cohort of young adult $(n=8)$ and aged $(n=15)$ rats was used to measure protein expression of mGluR subtypes in the whole mPFC. Experiment 2 used a second cohort of young adult $(n=8)$ and aged $(n=15)$ rats to assess expression of gene transcripts that encode mGluR subtypes in the PrL and IL subregions of the mPFC. In experiment 3 , young adult rats $(n=22)$ were used to probe the functional consequences of the age-related declines in mGluR expression identified in experiments 1 and 2, by evaluating the effects of pharmacological blockade of mGluR5 $(n=11)$ or mGluR2/3 $(n=11)$ in PrL on performance in a delayed response task used to assess working memory.

\section{Experiment 1: effect of age on expression of mGluR protein in the $\mathrm{mPFC}$}

Tissue dissection and protein extraction

Animals were killed by decapitation and the mPFC was micro-dissected from surrounding tissues on an ice-cold 
Table 1. Antibodies used for immunoblotting

\begin{tabular}{llllll}
\hline Primary antibody & Made in & Supplier & Part number & Dilution & Secondary antibody (dilution)* \\
Anti-mGluR1 & $\mathrm{Rb}$ & Millipore & $07-617$ & $1: 500$ & Dk anti-Rb IRDye 700 (1:20,000) \\
Anti-mGluR5 & $\mathrm{Ms}$ & Millipore & MABN540 & $1: 500$ & Dk anti-Ms IRDye 800 (1:15,000) \\
Anti-mGluR2/3 & $\mathrm{Rb}$ & Millipore & $06-676$ & $1: 1000$ & Dk anti-Rb IRDye 700 (1:20,000) \\
Anti-mGluR4 & $\mathrm{Rb}$ & Millipore & AB15097 & $1: 1000$ & Dk anti-Rb IRDye 800 (1:15,000) \\
Anti-mGluR7 & Gt & Abcam & ab85343 & $1: 1000$ & Dk anti-Gt IRDye 700 (1:20,000) \\
Anti-mGluR8 & Gt & Santa Cruz Biotechnology & sc-30300 & $1: 500$ & Dk anti-Gt IRDye 800 (1:15,000) \\
Anti- $\alpha$-tubulin & $\mathrm{Gk}$ & Sigma-Aldrich & SAB3500023 & $1: 2000$ & Dk anti-Ck IRDye 700 (1:20,000)
\end{tabular}

$\mathrm{Ck}=$ chicken, $\mathrm{Dk}=$ donkey, $\mathrm{Gt}=$ goat, $\mathrm{Ms}=$ mouse, $\mathrm{Rb}=$ rabbit.

* All secondary antibodies were purchased from LI-COR Bioscience.

plate before freezing on dry ice and storage at $-80^{\circ} \mathrm{C}$ until membranes were prepared (McQuail et al., 2012). All tissue samples were weighed and homogenized in 2-ml glass-Teflon dounce homogenizers containing ten volumes of $50 \mathrm{mM}$ HEPES ( $\mathrm{pH}$ 7.4) supplemented with $1 \mathrm{mM}$ EDTA, $1 \mathrm{mM}$ EGTA, and protease inhibitors (Halt from ThermoFisher). Tissue homogenates were transferred to a 1.5-ml tube, then centrifuged at $10,000 \times g$ for $20 \mathrm{~min}$ at $4^{\circ} \mathrm{C}$. The pellet, comprising the membrane-bound protein fraction, was resuspended in the same buffer and incubated on ice for $30 \mathrm{~min}$. All samples were then centrifuged at $20,000 \mathrm{rpm}(32,539 \times \mathrm{g})$ for $10 \mathrm{~min}$ at $4^{\circ} \mathrm{C}$. Finally, the washed pellet was resuspended in $50 \mathrm{mM}$ HEPES buffer, then aliquoted and stored at $-80^{\circ} \mathrm{C}$ until used for Western blot analyses.

\section{SDS-PAGE and immunoblotting}

Unless otherwise noted, all reagents used were from Bio-Rad. Each mPFC protein sample was diluted and reduced in Laemmli buffer with $5 \%(\mathrm{v} / \mathrm{v}) \beta$-mercaptoethaol and denatured at $95^{\circ} \mathrm{C}$ for $5 \mathrm{~min}$. A total of $5 \mu \mathrm{g}$ of membrane protein was loaded per well in a 26 lane TGX 4-15\% polyacrylamide gel. Each sample was assayed in duplicate and the location of each replicate was systematically varied between gels. Protein samples were separated for $45 \mathrm{~min}$ at $200 \mathrm{~V}$ in $1 \times$ running buffer (25 mM Tris, 192 $\mathrm{mM}$ glycine, and $0.1 \% \mathrm{SDS} ; \mathrm{pH}$ 8.3). Resolved proteins were electrophoretically transferred to nitrocellulose membranes $(0.45-\mu \mathrm{m}$ pore size) in $1 \times$ transfer buffer $(25 \mathrm{mM}$ Tris and $192 \mathrm{mM}$ glycine; $\mathrm{pH}$ 8.3) with $20 \%$ (v/v) methanol at 100 $\mathrm{V}$ for $30 \mathrm{~min}$ at $4^{\circ} \mathrm{C}$. Membranes were then blocked in Rockland Blocking buffer for $1 \mathrm{~h}$ at room temperature. Proteins of interest were detected by overnight incubation with specific primary antibodies (Table 1) diluted in blocking buffer supplemented with $0.1 \%$ Tween 20 at $4^{\circ} \mathrm{C}$. For each primary antibody, the optimal dilution was empirically determined to obtain a linear range of detection for 1.25-10 $\mu \mathrm{g}$ of $\mathrm{mPFC}$ membrane protein. Membranes were washed in $1 \times$ tris-buffered saline before incubation with IR-Dye conjugated secondary antibodies (Table 1). Excess secondary antibody was removed by washing with TBS $+0.1 \%$ Tween 20 (TBST) followed by additional washes of TBS. The membranes were then imaged on a LiCor Odyssey scanner and integrated intensity of immunoreactive bands was assessed using ImageStudio v3.2.

\section{Statistical analysis of protein levels \\ Integrated intensities were normalized using $\alpha$-tubulin} as a loading control, which did not change with age in any of the individual experiments ( $t \mathrm{~s}=0.238-0.397, p s=$ 0.695-0.814). Data were transformed to percentage level of young (i.e., mean level of young $=100 \%$ ) and analyzed by independent-samples $t$ test to compare protein levels between young and aged using the Benjamini-Hochberg method to correct for multiple comparisons with a false discovery rate (FDR) value (adjusted for the total number of protein comparisons) of $p_{(\mathrm{FDR})} \leq 0.05$ (Benjamini and Hochberg, 1995; Storey and Tibshirani, 2003). Statistical comparisons are summarized in Table 6.

\section{Experiment 2: effect of age on expression of mGluR mRNA in mPFC subregions}

Tissue micro-punching and RNA isolation

Animals were killed by rapid decapitation and whole brains were quickly extracted, frozen on dry ice, and stored at $-80^{\circ} \mathrm{C}$. Brains were equilibrated to $-10^{\circ} \mathrm{C}$ in a cryostat and $360-\mu \mathrm{m}$ sections were cut through the rostral-caudal extent of the frontal cortex. A 1-mm tissue biopsy punch tool was used to obtain samples from PrL and IL subregions of mPFC. Tissue punches were immediately transferred to homogenization buffer and total RNA was isolated using the RNEasy Plus Micro kit according to the manufacturer's protocol (PN: 74034, QIAGEN). RNA concentration was determined with the use of a NanoDrop1000 (Thermo Scientific). The yield of RNA was consistent and reproduced across groups. The average RNA integrity number (RIN) determined by TapeStation (Agilent Biosciences) was 9.7, and no sample had a RIN lower than 9.

\section{Reverse transcription and qPCR assay}

From each sample, $100 \mathrm{ng}$ of RNA was used to make cDNA using the $\mathrm{RT}^{2}$ PreAMP cDNA Synthesis kit (PN: 330451, QIAGEN). Then, cDNA targets were preamplified using the $\mathrm{RT}^{2}$ PreAMP PCR Mastermix and the $\mathrm{RT}^{2}$ PreAMP Pathway Primer Mix according to the manufacturer's protocol (PN: PBR-152Z, QIAGEN). Relative gene expression was measured using $\mathrm{RT}^{2}$ Profiler low-density PCR plates preloaded with qPCR primers for genes encoding GABA- and glutamate-related targets (PN: PARN-152ZA, QIAGEN). This approach was taken to enable assessment of all mGluR subtypes in parallel. Thermal cycling and data collection was accomplished using an ABI Real-Time PCR 7300. Only RT-qPCR plates that passed the PCR array reproducibility, reverse transcription efficiency, and genomic DNA contamination quality control parameters set by QIAGEN's preamplification methods $\left(\mathrm{RT}^{2}\right.$ Profiler PCR Array Data Analysis v3.5) as well as those reactions 
that produced the predicted peak by melting temperature $\left(T_{m}\right)$ curve analysis were included in the final analyses. Consequently, final group sizes for PrL and IL analyses were $n=6$ young and $n=12$ aged.

\section{Statistical analysis of genes}

Each gene included in the RT-qPCR plates was crossreferenced with the Allen Brain Institute's online in situ hybridization atlas (http://mouse.brain-map.org/) and those not expressed in MPFC were used to set the lowest cycle threshold $\left(\mathrm{C}_{t}\right)$ considered detectable. Genes were normalized to the housekeeping gene RPLP1. This gene did not differ by age in either PrL or IL (mean group difference $\left.=0.192 C_{t}\right)$. After normalization, $C_{t}$ values were transformed to percentage expression of young (i.e., mean level of young $=100 \%$ ). Independent-samples $t$ tests were used to compare expression of mGluR transcripts between young and aged samples in PrL and IL separately using the Benjamini-Hochberg method to correct for multiple comparisons with a FDR value (adjusted for the total number of gene comparisons) of $p_{(\mathrm{FDR})} \leq$ 0.00866 (Benjamini and Hochberg, 1995; Storey and Tibshirani, 2003). Statistical comparisons are summarized in Table 6.

\section{Experiment 3: contributions of mGluRs in PrL cortex to working memory}

Surgical procedures

Rats were anesthetized with isofluorane gas and secured in a stereotaxic frame. Following a midline incision over the skull, the skin was retracted and holes were drilled in the skull for guide cannulae and stainless-steel anchoring screws. Bilateral guide cannulae (22 gauge, Plastics One) targeting the PrL subregion of the mPFC (AP: $+2.7 \mathrm{~mm}$ from bregma, ML: $\pm 0.7 \mathrm{~mm}$ from bregma, DV: $-3.8 \mathrm{~mm}$ from the skull surface) were implanted and secured to the skull with the screws and dental cement. Stainless-steel obdurators were placed into the cannulae to minimize the risk of infection. Immediately after surgery, rats received subcutaneous injections of buprenorphine (1 $\mathrm{mg} / \mathrm{kg} / \mathrm{d}$ ) and meloxicam (2 mg/kg/d). Buprenorphine was also administered $24 \mathrm{~h}$ postoperation, and meloxicam 48-72 $\mathrm{h}$ postoperation. A topical ointment was applied as needed to facilitate wound healing. Before behavioral procedures, rats received at least two weeks postsurgical recovery, with sutures removed after 10-14 d.

\section{Behavioral testing apparatus}

Behavioral testing was conducted in 8 identical standard rat behavioral test chambers (Coulbourn Instruments) with steel front and back walls, transparent Plexiglas side walls, and a floor composed of steel rods (0.4 cm in diameter) spaced $1.1 \mathrm{~cm}$ apart. Each test chamber was housed in a sound-attenuating cubicle and was equipped with a recessed food pellet delivery trough located $2 \mathrm{~cm}$ above the floor in the center of the front wall. The trough was fitted with a photobeam to detect head entries and a 1.12-W lamp for illumination. Food rewards consisted of 45-mg grain-based food pellets (PJAI; Test Diet). Two retractable levers were positioned to the left and right of the food trough (11 cm above the floor). An additional 1.12-W house light was mounted near the top of the rear wall of the sound-attenuating cubicle. A computer interfaced with the behavioral test chambers and equipped with Graphic State 3.01 software (Coulbourn Instruments) was used to control experiments and collect data.

\section{Delayed response task}

Habituation and shaping of operant procedures

After rats recovered from surgery, they were foodrestricted to $85 \%$ of their free-feeding weights. Rats progressed through three stages of shaping before starting the working memory assessment. These shaping procedures were designed to train rats to reliably press each of the two response levers, with each new stage beginning on the day immediately following completion of a previous stage. On the day before shaping stage 1 , each rat was given five $45-\mathrm{mg}$ food pellets in its home cage to reduce neophobia to the food reward used in the task. Shaping stage 1 consisted of a 64-min session of magazine training, involving 38 deliveries of a single food pellet with an intertrial interval of $100 \pm 40 \mathrm{~s}$. Shaping stage 2 consisted of lever press training, in which a single lever (left or right, counterbalanced across age groups) was extended and a press resulted in delivery of a single food pellet. After reaching a criterion of 50 lever presses in $30 \mathrm{~min}$, rats were then trained on the opposite lever using the same procedures. During shaping stage 3 , a nose poke into the food trough caused either the left or right lever (counterbalanced across trials in this stage of testing) to extend, and a press resulted in a single food pellet delivery. Rats were trained in shaping stage 3 until achieving 80 lever presses in a 30-min session.

\section{Delayed response task procedures}

The task design was based on Sloan et al. (2006) and has been used by our lab previously to demonstrate working memory impairments in aged rats (Beas et al., 2013; Bañuelos et al., 2014; McQuail et al., 2016; Hernandez et al., 2017). Each 40-min session began with illumination of the house light, which remained illuminated throughout the entire session except during timeout periods. Rats received a single test session each day. Each trial in the task began with extension of a single "sample" lever into the chamber (Fig. 1). The sample lever (left or right) was randomly selected within each pair of trials to ensure equal representation of both levers across the test session. A press on the sample lever caused it to retract and initiated the delay interval. During the delay interval, rats were required to nose poke into the food trough to initiate the "choice phase." Because there were no cues that signaled the duration of the delay period, and because delays were randomized across trials (making it impossible for rats to predict the end of the delay), this requirement resulted in rats nose poking continuously until the choice phase was initiated. This requirement that rats nose poke in the food trough during the delay interval also reduced the likelihood that they could employ nonmnemonic, "mediating" strategies (e.g., positioning themselves in front of the sample lever during the delay). The first nose poke executed after the delay interval expired initiated the choice phase by causing both levers to ex- 

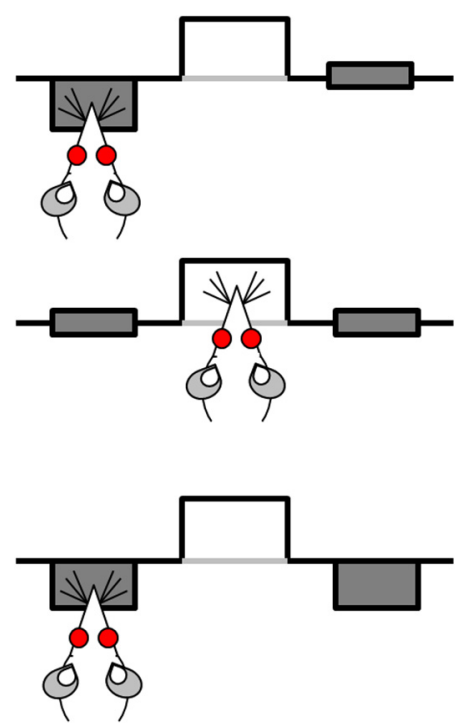

\section{Sample Phase (Left or Right)}

\author{
Delay Phase \\ (0-24 sec)
}

Figure 1. Schematic of delayed response working memory task. Each trial of the delayed response task includes three phases. During the sample phase, one lever (left or right, pseudo-randomly varied between pairs of trials) is extended into the chamber. The rat must press the extended lever to enter the variable duration "delay phase" (delays are pseudo-randomly varied from 0 to $24 \mathrm{~s}$ within each block of seven trials). During the delay, the rat must nose poke continuously into the centrally located food trough. The first nose poke emitted after the expiration of the predetermined delay timer initiates the choice phase wherein both levers (left and right) are extended into the chamber. The rat must remember and press the same lever that was extended during the sample phase to receive a food reward (a 45-mg food pellet), and this is scored as a correct choice. Pressing the other lever is scored as an incorrect choice and no food reward is delivered.

tend into the chamber. During the choice phase, a response on the same lever pressed during the sample phase was "correct" and resulted in retraction of both levers and delivery of a food pellet into the food trough, followed by a 5-s intertrial interval. A response on the opposite lever from that chosen during the sample phase was "incorrect" and resulted in retraction of both levers and initiation of a 5-s "timeout" period during which the house light was extinguished. Immediately following this timeout, the house light was re-illuminated and the next trial began (i.e., one lever was extended into the chamber for the "sample phase").

During initial sessions in this task, there were no delays between the sample and choice phases, and a correction procedure was used such that the sample lever was repeated on the same side following an incorrect response, to reduce development of side biases. Once rats reached a criterion of $80 \%$ correct choices across a test session for two consecutive sessions, this correction procedure was discontinued and a set of seven delays was introduced. The presentation of delay durations was randomized within each block of seven trials, such that each delay was presented once within a block. On establishing $>80 \%$ correct responses across two consecutive sessions in a "delay set," rats were progressed to the next set, which contained increasingly longer delays (delay set $1: 0,1,2,3,4,5$, and $6 \mathrm{~s}$; delay set $2: 0,2,4,8,12$, and 16 s; delay set $3: 0,2,4,8,12,18$, and 24 s). Rats were trained on the last delay set until reaching stable baseline performance (defined as $<10 \%$ variability across five consecutive days of training) at which point they were assigned to one of two drug groups used to test the effects of blockade of mGluR5 and mGluR2/3 (counterbalancing baseline performance across groups).

\section{Drug preparation and intracerebral micro-infusion}

The selective noncompetitive mGluR5 antagonist (Anderson et al., 2002; Busse et al., 2004) 3-((2-methyl-4thiazolyl)ethynyl)pyridine (MTEP; Tocris), was dissolved in artificial CSF (aCSF) at concentrations of $0.1,0.3$, and 1.0 $\mu \mathrm{g}$ per $0.5 \mu \mathrm{l}$. Doses were selected based on a previous study showing that intracerebral infusions targeting the mPFC with $15 \mathrm{nmol}(3.5 \mu \mathrm{g})$ of MTEP per hemisphere prevented behavioral sensitization to cocaine (Timmer and Steketee, 2012). The mixed mGluR2/3 competitive antagonist (Kingston et al., 1998), (2S)-2-amino-2-[(1S,2S)2-carboxycycloprop-1-yl]-3-(xanth-9-yl) propanoic acid (LY341495, Tocris), was dissolved in a $20 \%$ DMSO in aCSF solution at concentrations of $0.005,0.05$, and 0.5 $\mu \mathrm{g}$ per $0.5 \mu \mathrm{l}$. Doses were selected according to a previous study showing that intracerebral infusions targeting the amygdala with $0.3 \mu \mathrm{g}$ of LY341495 per hemisphere blocked a Group II mGluR agonist-induced startle response (Walker et al., 2002).

After establishing baseline performance, rats were assigned to receive either MTEP or LY341495. Drug doses were administered using a randomized, within-subjects Latin square design such that each rat received each dose of drug and vehicle, with a 48-h washout period between successive infusions. Each infusion was administered by an experimenter who was blinded to the treatment conditions. Drugs were administered using 10- $\mu$ l Hamilton syringes mounted on a Harvard Apparatus infusion pump (Pump 11 Elite, Harvard Apparatus) and con- 

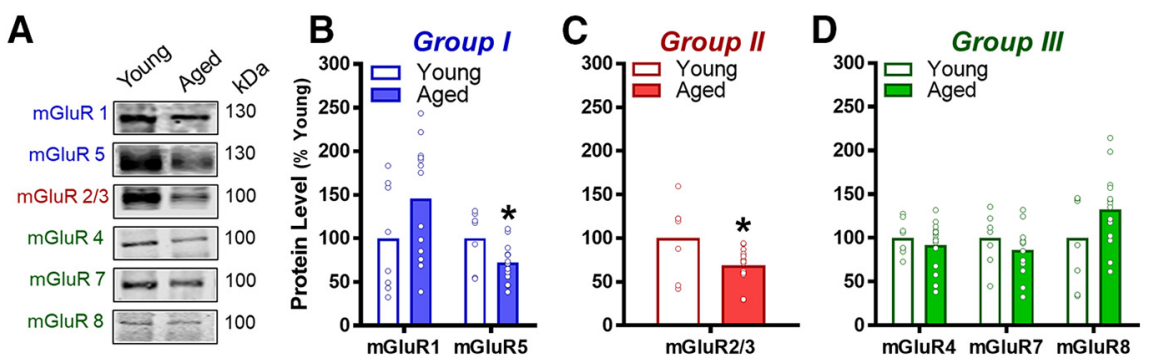

Figure 2. mGluR protein levels in mPFC of young and aged rats. $\boldsymbol{A}$, Representative images of immuno-reactive bands detected using mGluR subtype-selective antibodies in whole mPFC membrane homogenates prepared from young and aged rats. $\boldsymbol{B}$, Group I mGluRs (in blue). The protein level of mGluR5, but not mGluR1, was significantly lower in the mPFC of aged rats compared to young adults (*p $<0.05$ vs young). C, Group II mGluRs (in red). The protein level of mGluR2/3 was significantly lower in the mPFC of aged rats compared to young adults ( $* p<0.05$ vs young). $\boldsymbol{D}$, Group III mGluRs (in green). There were no significant changes to the protein levels of Group III mGluRs of aged rats compared to young adults ( $p>0.05$ vs young). $\boldsymbol{B}-\boldsymbol{D}$, Mean protein level (transformed to "\% of young" after normalizing integrated intensity to $\alpha$-tubulin, $y$-axis; see Table 2 for normalized, untransformed data) is plotted as a function of mGluR subtype ( $x$-axis) and age group (separate bars; $n=7-8$ young and $n=15$ aged). Open circles represent values for individual rats and bars represent group means.

nected via PE-20 tubing to micro-injectors (Plastics One), which extended $1 \mathrm{~mm}$ past the end of the guide cannulae. Each dose was delivered in a volume of $0.5 \mu \mathrm{l} / \mathrm{hemisphere}$ over a duration of $1 \mathrm{~min}$, and injectors were left in place for one additional minute to allow for diffusion. Behavioral testing began 5 min postinfusion.

\section{Cannula placement histology}

After completion of behavioral testing, rats were administered a lethal dose of Euthasol (sodium pentobarbital and phenytoin solution; Virbac) and perfused transcardially with a $4^{\circ} \mathrm{C}$ solution of $0.1 \mathrm{M}$ PBS for $2 \mathrm{~min}$, followed by $4 \%(\mathrm{w} / \mathrm{v})$ paraformaldehyde in $0.1 \mathrm{M}$ PBS for an additional $5 \mathrm{~min}$. Brains were removed and postfixed for $24 \mathrm{~h}$, then transferred to a $20 \%(\mathrm{w} / \mathrm{v})$ sucrose solution in $0.1 \mathrm{M}$ PBS for $3 \mathrm{~d}$ (all chemicals purchased from Fisher Scientific). Brains were sectioned at $40 \mu \mathrm{m}$ using a cryostat maintained at $-20^{\circ} \mathrm{C}$, and slices were mounted on electrostatic glass slides. Brain sections were subsequently stained with thionin and coverslipped for verification of cannula placement under a compound light microscope. Injector tip coordinates were identified using a rat brain atlas (Paxinos and Watson, 2005). Off-target cannula placements required exclusion of $n=4$ rats from the MTEP cohort (for finalized cannula placements, see Fig. $4 A$ ) and $n=1$ rat from the LY341495 cohort (for finalized cannula placements, see Fig. $5 A$ ).

\section{Statistical analyses for behavioral pharmacology}

Raw data files were exported from Graphic State software and compiled using a custom macro written for Microsoft Excel (Dr. Jonathan Lifshitz, University of Kentucky). Statistical analyses were conducted using SPSS 24.0 (IBM). Choice accuracy (the percentage of correct choices at each delay duration) was the primary measure of interest (Beas et al., 2013; Bañuelos et al., 2014; McQuail et al., 2016; Hernandez et al., 2017). Several additional measures were also compared to assess possible non-mnemonic effects on task performance (number of trials completed/session, see Figs. 4, 5; and latency to lever press during both the sample and choice phases of the trials, see Tables 4, 5). Choice accuracy was analyzed using a two-factor, repeated-measures ANOVA, with drug dose (four levels) and delay (seven levels) as withinsubjects factors. The Huynh-Feldt correction was applied to correct for violations of sphericity. Significant main effects of dose or interactions between dose and delay were explored with a post hoc, two-factor, repeatedmeasures ANOVA to compare the effect of individual doses versus vehicle (two levels), with delay (seven levels) as an additional within-subjects factor in these analyses. To determine the effect of dose at specific delays, a post hoc, repeated-measures ANOVA was done with dose (four levels) as the within-subjects factor for each individual delay. Any significant effects of dose were followed up with a pairwise comparison using paired-samples $t$ tests with Dunnett's correction for multiple comparisons. The number of trials completed and lever press latencies were analyzed using a one-factor, repeated-measures ANOVA, with drug dose (four levels) as the within-subjects factor. The Huynh-Feldt correction was applied to correct for violations of sphericity. To determine whether there were carry-over or cumulative effects of successive PrL microinfusions, choice accuracy on intervening wash-out days was analyzed by a repeated-measures ANOVA, using either dose delivered on the previous day or cumulative number of micro-infusions (four levels for each) as withinsubjects factors. Statistical comparisons are summarized in Table 6.

\section{Results}

\section{Experiment 1: expression of select mGluR proteins is reduced in aged PFC}

Group I mGluRs are largely localized to postsynaptic sites and include mGluR1 and mGluR5. Expression of mGluR1 in the mPFC did not reliably differ between young adult and aged rats $\left(t_{(21)}=-1.670, p=0.110\right.$; Fig. $\left.2 B\right)$; however, expression of mGluR5 was significantly decreased in aged relative to young $\left(t_{(20)}=2.407, p=0.026\right.$; Fig. 2B). Group II mGluRs are comprised of mGluR2 and mGluR3, and these receptors have been identified on both pre- and postsynaptic sites (Tanabe et al., 1993; Okamoto et al., 1994; Mannaioni et al., 2001; Sansig et al., 
Table 2. Age effects on protein levels in the mPFC (untransformed normalized protein values)

\begin{tabular}{lllll}
\hline Protein & Young & Aged & $\Delta$ from young & $t_{(20-21)}, p$ value \\
mGluR1 & $20,307.25 \pm 4395.02$ & $29,617.20 \pm 3327.26$ & 9309.95 & $t_{(21)}=-1.67, p=0.110$ \\
mGluR5 & $82,644.20 \pm 10,450.19$ & $59,508.56 \pm 4488.32$ & $-23,135.65$ & $t_{(20)}=2.407, p=0.026$ \\
mGluR2/3 & $725,810.54 \pm 119,325.75$ & $498,933.86 \pm 36,495.67$ & $-226,876.68$ & $t_{(20)}=2.366, p=0.028$ \\
mGluR4 & $50,511.34 \pm 3501.51$ & $46,345.35 \pm 3556.84$ & -4165.99 & $t_{(21)}=0.754, p=0.459$ \\
mGluR7 & $1,389,307.48 \pm 141,709.53$ & $1,199,490.29 \pm 96,296.40$ & $-18,9817.20$ & $t_{(21)}=1.134, p=0.270$ \\
mGluR8 & $5268.93 \pm 941.36$ & $6971.13 \pm 565.52$ & 1702.20 & $t_{(21)}=-1.649, p=0.114$ \\
\hline
\end{tabular}

2001; Tyszkiewicz et al., 2004; Hagenston et al., 2008; Niswender and Conn, 2010; Arnsten et al., 2012; Jin et al., 2017). Although antibodies do not distinguish between these receptors, expression of mGluR2/3 was also significantly lower in the aged mPFC compared to young $\left(t_{(20)}=\right.$ 2.366, $p=0.028$; Fig. $2 C$ ). In contrast, expression of the largely presynaptic Group III receptors, mGluR4, mGluR7, and mGluR8, was unchanged with age $\left(t \mathrm{~s}_{(21)}=-1.650-\right.$ 1.134, ps = 0.114-0.459; Fig. 2D). See Table 2 for normalized data (not expressed as percentage of young) and note that mGluR6 is not expressed in brain and thus was not analyzed.

\section{Experiment 2: age-associated reductions in mGluR mRNA expression are PFC subregion specific}

To confirm and extend the significant findings observed at the level of mGluR protein, complementary analyses were performed to measure expression of mRNAs that encode for these receptors in a second cohort of young and aged rats. Relative to Western blotting, PCR requires comparatively smaller sample quantities, allowing for differentiation of the MPFC into PrL and IL subregions for discrete analyses. Further, unlike commercial antibodies, PCR primer probes can distinguish between GRM2 and GRM3. Table 3 and Figure 3 summarize statistical comparisons of mGluR gene expression in young and aged rats using this analysis. In agreement with the data from Western blots, both GRM5 and GRM3 were significantly reduced in aged PrL. Expression of GRM4 also was reliably reduced in aged PrL compared to young. Expression of GRM7, GRM8, GRM1, and GRM2 was preserved in aged PrL relative to young. In contrast to selective mGluR mRNA reductions in PrL, expression of mRNA for all mGluR subtypes did not differ as a function of age in IL.
See Table 3 for normalized data (not expressed as percentage of young).

\section{Experiment 3: mGluR3 and mGluR5 in PrL are necessary for normal working memory}

Data from mGluR protein and gene expression studies converge to potentially implicate reductions in specific mGluRs in the age-associated decline of cognitive processes supported by the mPFC. Specifically, findings from experiments 1 and 2, together with a large literature implicating PFC in working memory, suggest that the decline of mGluR5 and mGluR3 in the aged PrL might contribute to the well-documented impairments in this aspect of cognition that emerge in later life (OscarBerman and Bonner, 1985; Dunnett et al., 1988; Rapp and Amaral, 1989; Bachevalier et al., 1991; Lamar and Resnick, 2004; Beas et al., 2013; McQuail et al., 2016; Hernandez et al., 2017). The final experiments in this study were designed to determine whether these mGluR reductions could be sufficient to impact working memory performance. In these studies, two cohorts of young adult rats were used to test the effects of intra-PrL microinfusions of selective mGluR antagonists targeting mGluR5 or mGluR2/3 on performance in a delayed response task that evaluates working memory.

In the first cohort of rats, the effects on working memory resulting from blockade of the group I receptor mGluR5 were tested using the selective mGluR5 antagonist MTEP. Intra-PrL infusion of MTEP significantly impaired choice accuracy (Fig. 4B; main effect of dose: $F_{(3,18)}=3.176, p=$ 0.049; dose $\times$ delay interaction: $F_{(18,108)}=1.096, p=$ 0.366). Post hoc comparisons probing individual doses relative to vehicle indicated that the $0.3-\mu \mathrm{g}$ dose of MTEP reliably impaired choice accuracy (Fig. 4C,D; main effect

Table 3. Age effects on gene expression in the PrL and the IL (untransformed normalized RNA values)

\begin{tabular}{llllll}
\hline Gene & Subregion & Young & Aged & $\Delta$ from young & $t_{(16)}, p$ value \\
GRM1 & PrL & $0.002235 \pm 0.000978$ & $0.001937 \pm 0.000645$ & -0.000299 & $t_{(16)}=0.261, p=0.798$ \\
& IL & $0.002033 \pm 0.000908$ & $0.001286 \pm 0.000427$ & -0.000747 & $t_{(16)}=-0.854, p=0.406$ \\
GRM5 & PrL & $0.054026 \pm 0.007805$ & $0.028365 \pm 0.004163$ & -0.025661 & $t_{(16)}=3.200, p=0.006$ \\
& IL & $0.041180 \pm 0.010800$ & $0.041917 \pm 0.009986$ & 0.000737 & $t_{(16)}=-0.046, p=0.964$ \\
GRM2 & PrL & $0.028930 \pm 0.004422$ & $0.021187 \pm 0.003913$ & -0.007744 & $t_{(16)}=1.213, p=0.243$ \\
& IL & $0.013810 \pm 0.002117$ & $0.014570 \pm 0.002094$ & 0.000760 & $t_{(16)}=-0.230, p=0.823$ \\
GRM3 & PrL & $0.056213 \pm 0.004957$ & $0.032051 \pm 0.005106$ & -0.024162 & $t_{(16)}=2.990, p=0.009$ \\
& IL & $0.041953 \pm 0.007275$ & $0.050947 \pm 0.010043$ & 0.008994 & $t_{(16)}=-0.589, p=0.479$ \\
GRM4 & PrL & $0.009190 \pm 0.001015$ & $0.005563 \pm 0.000669$ & -0.003627 & $t_{(16)}=3.058, p=0.008$ \\
& IL & $0.006980 \pm 0.001232$ & $0.008730 \pm 0.001687$ & 0.001750 & $t_{(16)}=-0.682, p=0.505$ \\
GRM7 & PrL & $0.040217 \pm 0.005571$ & $0.025655 \pm 0.004430$ & -0.014562 & $t_{(16)}=1.963, p=0.067$ \\
& IL & $0.029601 \pm 0.007437$ & $0.033461 \pm 0.007364$ & 0.003861 & $t_{(16)}=-0.329, p=0.746$ \\
GRM8 & PrL & $0.016475 \pm 0.002306$ & $0.010738 \pm 0.001938$ & -0.005737 & $t_{(16)}=1.793, p=0.092$ \\
& IL & $0.010927 \pm 0.002872$ & $0.014094 \pm 0.003378$ & 0.003167 & $t_{(16)}=-0.605, p=0.554$
\end{tabular}



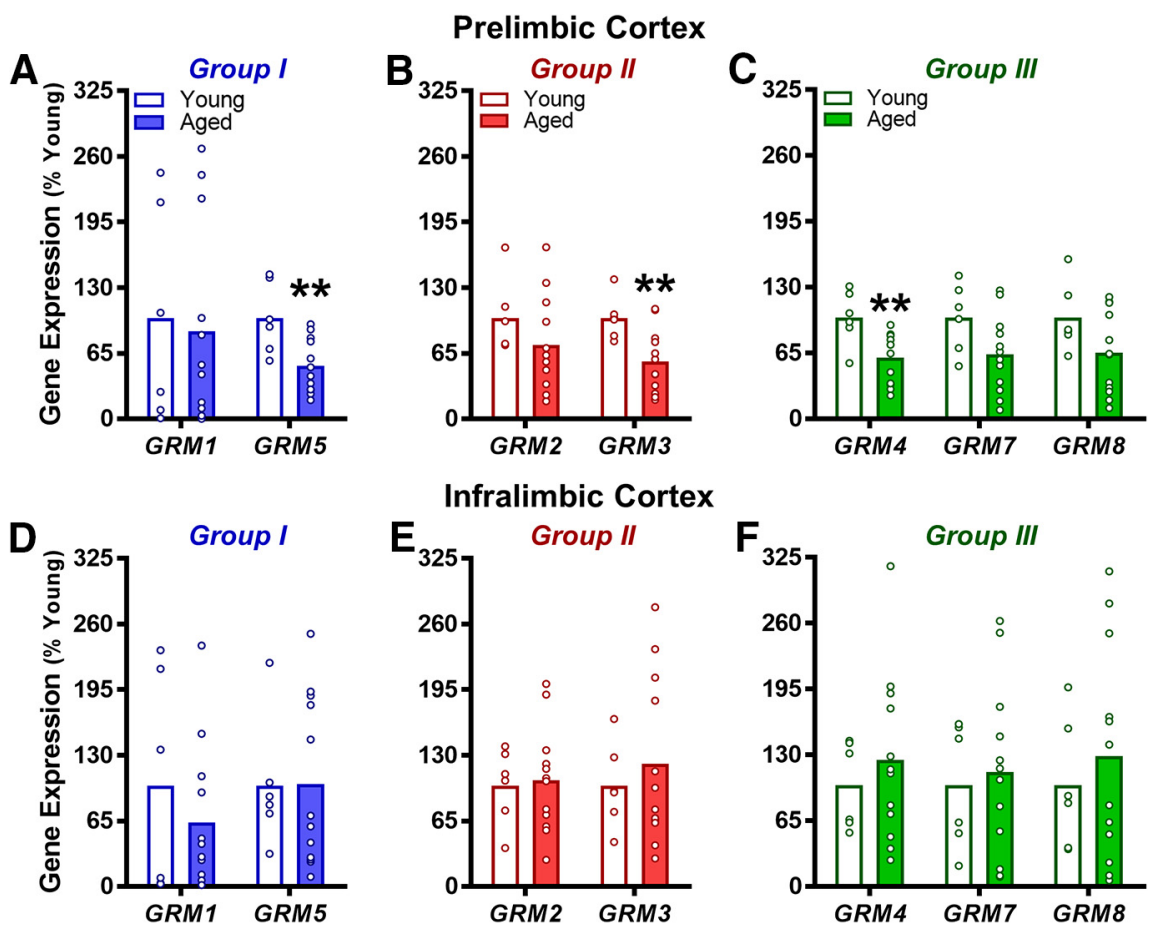

Figure 3. mGluR gene transcript expression in the PrL and IL of young and aged rats. $\boldsymbol{A}$, Group I mGluRs (in blue). Expression of GRM5, but not GRM1, was significantly lower in the PrL subregion of aged rats compared to young adults ( $* * p<0.01 \mathrm{vs}$ young). $\boldsymbol{B}$, Group II mGluRs (in red). Expression of GRM3, but not GRM2, was significantly lower in the PrL of aged rats compared to young adults (**p $<0.01$ vs young). C, Group III mGluRs (in green). Expression of GRM4, but not GRM7 or GRM8, was significantly lower in the PrL of aged rats compared to young adults (**p $<0.01$ vs young). $\boldsymbol{D}-\boldsymbol{F}$, Gene expression was not significantly different between young adult and aged rats in the IL subregion. In all panels, mean gene expression (transformed to "\% of young" after normalizing raw $\mathrm{C}_{t}$ values to RPLP1; $y$-axis) is plotted as a function of gene ( $x$-axis) and age group (separate bars; $n=6$ young and $n=12$ aged). Open circles represent values for individual rats and bars represent group means.

of dose: $F_{(1,6)}=54.178, p=0.0001$; dose $\times$ delay: $F_{(6,36)}$ $=1.388, p=0.246$ ), whereas performance under other doses did not significantly differ from vehicle (main effects of dose $F \mathrm{~s}_{(1,6)}=0.024-2.44$, ps $=0.639-0.882$; dose $\times$ delay interactions: $F_{s_{(6,36)}}=0.765-1.186, p s=0.336-$ 0.602). To evaluate potential carry-over effects of the drug micro-infusions, performance on intervening days of the drug schedule (i.e., wash-out days) was also evaluated. Performance on these days did not differ as a function of either the dose administered on the previous day (main effect of prior day's dose: $F_{(3,18)}=0.239, p=0.868$; data not shown) or as a function of infusion day (main effect of infusion day: $F_{(3,18)}=1.205, p=0.334$; data not shown), indicating there were no residual effects of MTEP on task performance that carried forward to subsequent drug days, nor deleterious effects on task performance from the cumulative effects of successive micro-infusions. To determine whether MTEP influenced non-mnemonic aspects of task performance, several additional measures were also assessed. Analysis of the total number of trials completed per session revealed no effect of MTEP dose (Fig. $4 E ; F_{(3,18)}=0.571, p=0.642$ ). Additional analyses of lever press response latencies revealed no effects of MTEP dose during either the sample $\left(F_{(3,18)}=1.149, p=\right.$ $0.356)$ or choice (matching) $\left(F_{(3,18)}=2.55, p=0.088\right)$ phases of the task (Table 4). These data suggest that the effects of MTEP on delayed response choice accuracy were not secondary to effects on motivation or general task performance.

In the second cohort of rats used for behavioral pharmacology, the effects on working memory resulting from blockade of group II receptors (mGluR2/3) were tested using LY341495. A main effect of dose $\left(F_{(3,27)}=\right.$ 4.778, $p=0.008$ ) and a significant dose $\times$ delay interaction $\left(F_{(18,162)}=2.083, p=0.009\right)$ on choice accuracy were observed following LY341495 administration (Fig. $5 B$ ). Post hoc analyses comparing individual doses to vehicle determined that all doses significantly impaired performance (5 ng, main effect of dose: $F_{(1,9)}=0.570, p=$ 0.470 ; dose $\times$ delay interaction: $F_{(6,54)}=2.834, p=$ $0.018 ; 50 \mathrm{ng}$, main effect of dose: $F_{(1,9)}=1.895$, $p=0.202$; dose $\times$ delay interaction: $F_{(6,54)}=2.887, p=$ $0.029 ; 500 \mathrm{ng}$, main effect of dose: $F_{(1,9)}=14.911, p=$ 0.004 , dose $\times$ delay: $F_{(6,54)}=1.793, p=0.118$, Fig. $\left.5 C, D\right)$. A further post hoc analysis on the effect of dose at each delay revealed significant main effects of dose at both the 18 -s delay $\left(F_{(3,27)}=5.009, p=0.007\right.$; veh $>5$ ng: $t_{(9)}=$ $2.501, p=0.034$; veh $>50$ ng: $t_{(9)}=3.212, p=0.011$; veh $>500$ ng: $\left.t_{(9)}=2.596, p=0.029\right)$ and $24-\mathrm{s}$ delay $\left(F_{(3,27)}=\right.$ $3.570, p=0.027$; veh $>500$ ng: $t_{(9)}=2.402, p=0.040$; see Table 6 for summary of all post hoc analyses). As with MTEP, there was no residual effect of LY341495 on task performance on the wash-out days following drug infusion (main effect of prior day's dose: $F_{(3,27)}=1.341, p=$ 

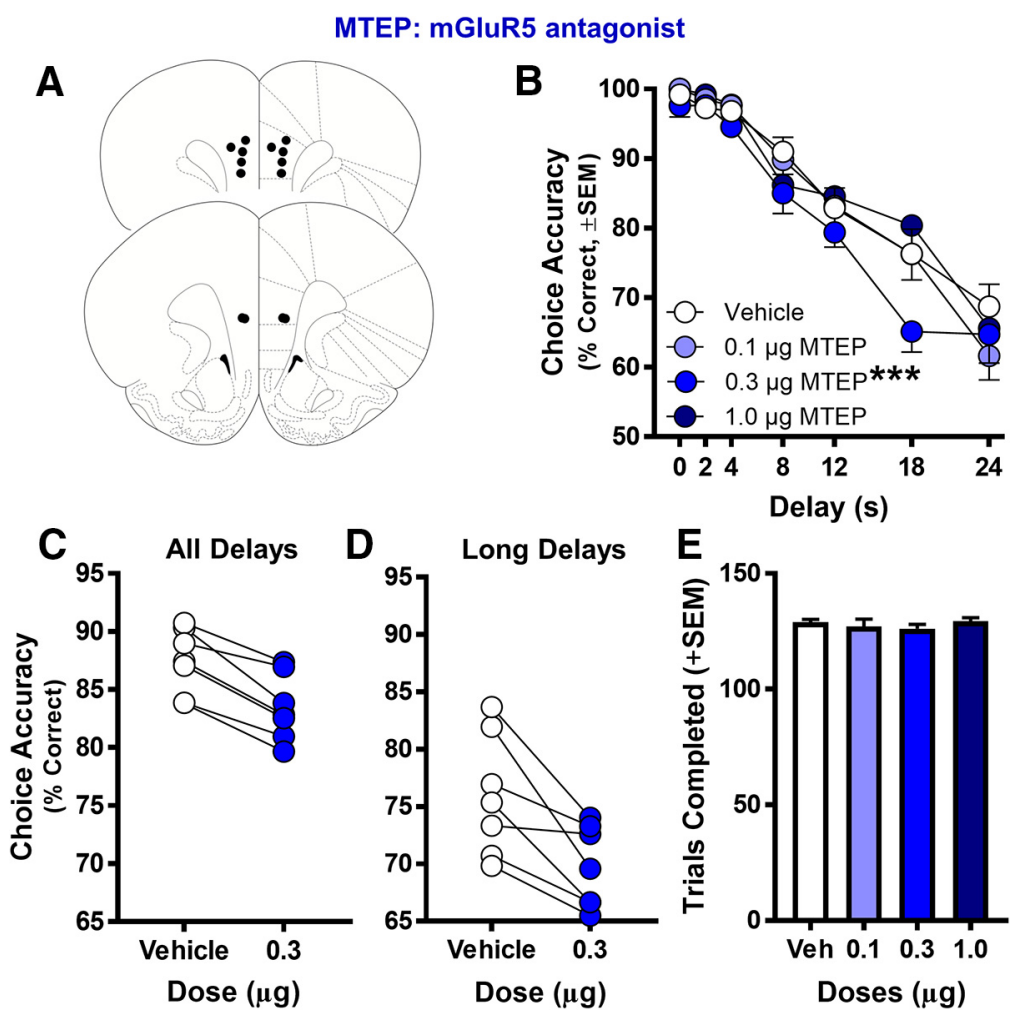

Figure 4. Effect of micro-infusing MTEP (mGluR5 antagonist) into PrL cortex on performance in the delayed response working memory task. $\boldsymbol{A}$, Histologically verified placements of injector tips used to micro-infuse the mGluR5 antagonist MTEP into the PrL cortex of young adult rats before testing in the delayed response task ( $n=7$ young rats). $\boldsymbol{B}$, Micro-infusion of $0.3-\mu \mathrm{g}$ MTEP significantly reduced choice accuracy relative to vehicle $(n=7 ; * * * p<0.05$ vs vehicle, main effect of dose). $\boldsymbol{C}$, Post hoc analysis comparing $0.3-\mu \mathrm{g}$ dose of MTEP to vehicle. The $0.3-\mu \mathrm{g}$ dose of MTEP impaired performance across all delays in all rats compared to vehicle performance, $p<0.001$. $\boldsymbol{D}$, The $0.3-\mu \mathrm{g}$ dose of MTEP impaired performance at long delays (12-24 s) in all rats compared to vehicle performance. $\boldsymbol{E}$, The number of trials completed did not change as a function of MTEP dose. In $\boldsymbol{A}$, placements are mapped to standardized coronal sections corresponding to +2.70 and $+3.20 \mathrm{~mm}$ from bregma according to the atlas of Paxinos and Watson (2005). In $\boldsymbol{B}$, mean choice accuracy ( $y$-axis) is plotted as a function of delay ( $x$-axis) and dose (symbols/lines; refer to legend for specific dose). In $\boldsymbol{C}, \boldsymbol{D}$, mean choice accuracy (collapsed across all delays in $\boldsymbol{C}$ and long delays (12-24 s) in $\boldsymbol{D} ; y$-axis) is plotted as a function of the $0.3-\mu \mathrm{g}$ dose of MTEP ( $x$-axis; symbols/lines). Error bars represent the SEM.

0.282; data not shown) nor did the cumulative number of micro-infusions influence performance (main effect of infusion day: $F_{(3,27)}=0.276, p=0.842$; data not shown). Finally, LY341495 had no effects on either the number of trials completed $\left(F_{(3,27)}=2.422, p=0.088\right.$; Fig. $\left.5 E\right)$ or lever press response latencies (sample phase: $F_{(3,27)}=$ $2.017, p=0.185$; choice (matching) phase $F_{(3,27)}=1.000$, $p=0.408$; Table 5).

Table 4. Effects of MTEP (mGluR5 antagonist) on response latencies

\begin{tabular}{lllll}
\hline Response latency & Dose & Mean $(\mathrm{ms})$ & SE & $N$ \\
Sample phase & Vehicle & 1729.74 & 103.44 & 7 \\
$F_{(3,18)}=1.149, p=0.356$ & $0.1 \mu \mathrm{g}$ & 2213.25 & 388.26 & 7 \\
& $0.3 \mu \mathrm{g}$ & 2422.28 & 305.92 & 7 \\
Matching phase & $1.0 \mu \mathrm{g}$ & 1893.21 & 224.53 & 7 \\
$F_{(3,18)}=2.55, p=0.088$ & Vehicle & 1013.31 & 82.56 & 7 \\
& $0.1 \mu \mathrm{g}$ & 1014.81 & 90.96 & 7 \\
& $0.3 \mu \mathrm{g}$ & 1017.94 & 66.11 & 7 \\
& $1.0 \mu \mathrm{g}$ & 942.91 & 91.39 & 7
\end{tabular}

\section{Discussion}

The goal of this study was to compare expression of all known mGluR subtypes in the mPFC between fully mature young adult and aged rats, and to differentiate the effects of selective mGluR antagonists in MPFC on normal working memory. Experiments 1 and 2 were directed at evaluating both protein and mRNA expression of mGluRs in aging, using complementary methodology in independent cohorts of young adult and aged rats. The biochemical analysis indicated that expression of mGluR2/3 and mGluR5 was reliably reduced with age. While arguably the protein expression data provide the most functionally-relevant information regarding the influence of age on these receptors, current antibodies do not distinguish between several of the mGluRs. Moreover, the quantity of tissue required for reliable protein assessment makes it difficult to restrict the analysis to anatomically and functionally distinct mPFC subregions (specifically PrL and IL). To provide confirmatory and complementary data regarding subregional $m$ GluR expression, the mRNA transcripts for each receptor were probed using low density, PCR-based arrays that included genes for all known 

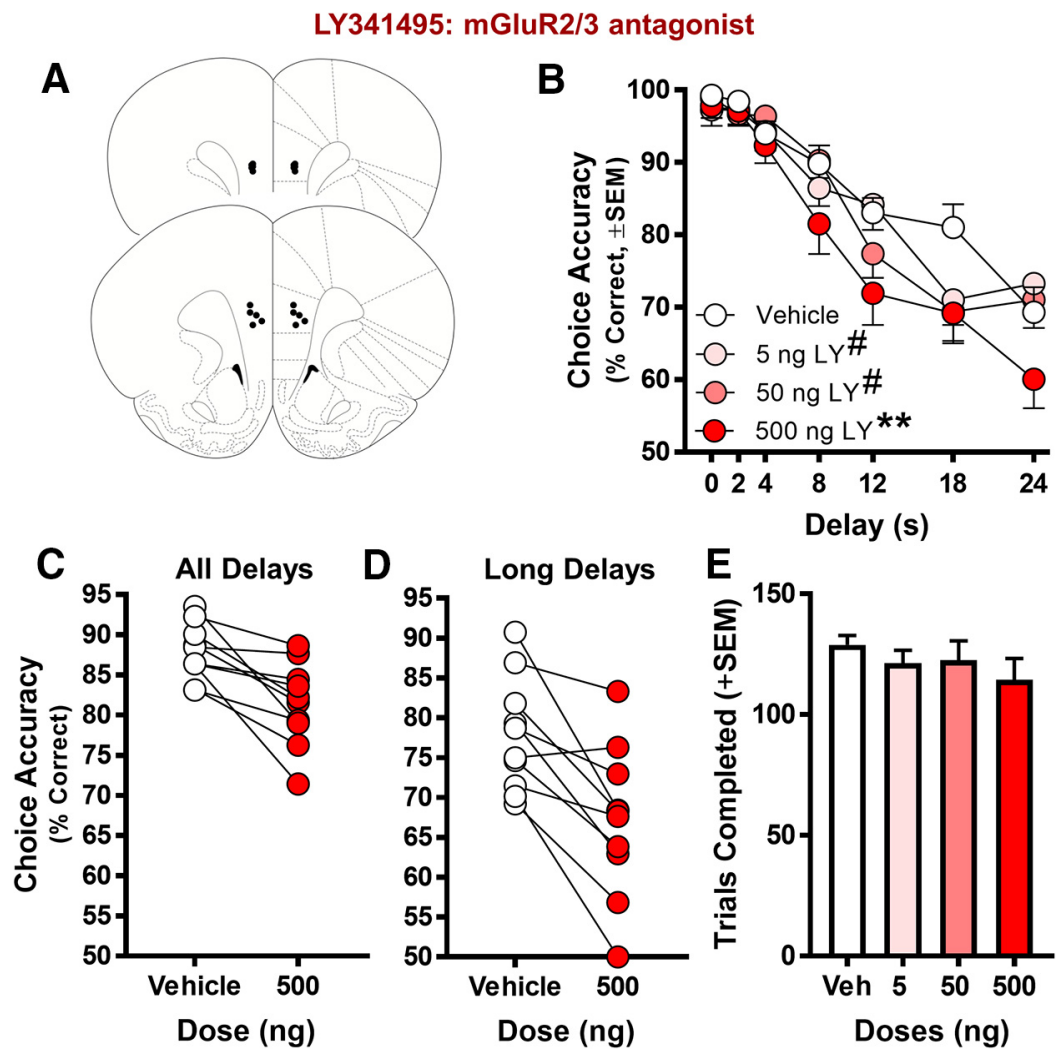

Figure 5. Effect of micro-infusing LY341495 (mGluR2/3 antagonist) into PrL cortex on performance in the delayed response working memory task. $\boldsymbol{A}$, Histologically verified placements of injector tips used to micro-infuse the mGluR2/3 antagonist LY341495 into the PrL cortex of young adult rats before testing in the delayed response task ( $n=10$ young rats). B, Microinfusion of LY341495 significantly reduced choice accuracy relative to vehicle at all doses tested $(n=10 ; * * p<0.05$ vs vehicle, main effect of dose; \#p $<0.05$ vs vehicle, dose $\times$ delay interaction). $\boldsymbol{C}$, Post hoc analysis comparing 500-ng dose of LY341495 to vehicle. The 500-ng dose impaired performance across all delays in all rats compared to vehicle performance, $p<0.01$. D, Micro-infusion of 500 -ng LY341495 impaired performance at long delays (12-24 s) compared to vehicle performance. $\boldsymbol{E}$, The number of trials completed did not change as a function of dose. In $\boldsymbol{A}$, placements are mapped to standardized coronal sections corresponding to +2.70 and +3.20 mm from bregma according to the atlas of Paxinos and Watson (2005). In $\boldsymbol{B}$, mean choice accuracy ( $\boldsymbol{y}$-axis) is plotted as a function of delay ( $x$-axis) and dose (symbols/lines; refer to legend for specific dose). In $\boldsymbol{C}, \boldsymbol{D}$, mean choice accuracy (collapsed across all delays in $\boldsymbol{C}$ and long delays (12-24 s) in $\boldsymbol{D} ; y$-axis) is plotted as a function of the 500-ng dose of LY341495 ( $x$-axis; symbols/lines). Error bars represent the SEM.

mGluRs (GRM1-8). This strategy allowed expression of GRM2 and GRM3 to be differentiated in addition to enabling the effects of age to be isolated in PrL and IL subregions. This approach corroborated the loss of mGluR5 and specified that loss of mGluR2/3 detected at the protein level is likely attributable to lower GRM3 expression. Importantly, these data agree with postmortem studies that were prospectively designed to compare

Table 5. Effects of LY341495 (mGluR2/3 antagonist) on response latencies

\begin{tabular}{lllll}
\hline Response latency & Dose & Mean $(\mathrm{ms})$ & SE & $N$ \\
Sample phase & Vehicle & 1915.99 & 447.33 & 10 \\
$F_{(3,27)}=2.017, p=0.185$ & $5 \mathrm{ng}$ & 3014.86 & 971.06 & 10 \\
& $50 \mathrm{ng}$ & 2948.58 & 1379.83 & 10 \\
& $500 \mathrm{ng}$ & 4907.86 & 2351.06 & 10 \\
Matching phase & Vehicle & 1059.35 & 106.66 & 10 \\
$F_{(3,27)}=1.0, p=0.408$ & $5 \mathrm{ng}$ & 1191.25 & 120.88 & 10 \\
& $50 \mathrm{ng}$ & 1108.37 & 83.11 & 10 \\
& $500 \mathrm{ng}$ & 1173.37 & 104.58 & 10
\end{tabular}

mGluR expression in PFC between schizophrenia patients and healthy controls, but incidentally observed that expression of both mGluR2/3 and mGluR5 are negatively correlated with age (Crook et al., 2002; Corti et al., 2011; Frank et al., 2011).

At the mRNA level, the loss of mGluRs was localized to the PrL subregion of the mPFC. The significance of this subregion-specific effect may pertain to unique characteristics of the PrL that support mnemonic function, due in part to extensive interconnections with other corticolimbic brain regions (Seamans et al., 1995; Vertes, 2004, 2006; Cassaday et al., 2014). In contrast, the neighboring IL subregion, which exhibited no significant age-related changes in expression of mGluR genes, is known to connect more extensively with subcortical targets to regulate autonomic viscero-motor processes (Vertes, 2004 , 2006). Indeed, pharmacological inactivation, or optogenetic manipulation localized to the PrL demonstrates that this mPFC subregion is required for behaviors that engage working memory (Sierra-Mercado 
Table 6. Summary of statistical analyses

\begin{tabular}{|c|c|c|c|c|c|c|c|c|c|}
\hline & Measure & Factor(s) & Level(s) & $\begin{array}{l}\text { Data structure: normality tests } \\
\text { Kolmogorov-Smirnov } \\
\text { ( } t \text { test); } \\
\text { Mauchly's sphericity (ANOVAs) }\end{array}$ & Type of test & $\begin{array}{l}\text { Statistical } \\
\text { value }\end{array}$ & $p$ value & $\begin{array}{l}\text { Effect size: } \\
\text { Cohen's } d \text { ( } t \text { test); } \\
\text { partial } \eta^{2} \\
\text { (ANOVA) }\end{array}$ & $\begin{array}{l}\text { Observed } \\
\text { power }\end{array}$ \\
\hline $\bar{a}$ & $\begin{array}{l}\text { mGluR1 protein level in } \\
\text { whole mPFC }\end{array}$ & Age & 2 & Normal & $t$ test (FDR-corrected) & $t=-1.670$ & 0.110 & 0.740 & 0.380 \\
\hline b & $\begin{array}{l}\text { mGluR5 protein level in } \\
\text { whole mPFC }\end{array}$ & Age & 2 & Normal & $t$ test (FDR-corrected) & $t=2.407$ & 0.026 & 1.000 & 0.449 \\
\hline c & $\begin{array}{l}\text { mGluR2/3 protein level } \\
\text { in whole mPFC }\end{array}$ & Age & 2 & Normal & $t$ test (FDR-corrected) & $t=2.366$ & 0.028 & 0.928 & 0.350 \\
\hline d & $\begin{array}{l}\text { mGluR4 protein level in } \\
\text { whole mPFC }\end{array}$ & Age & 2 & Normal & $t$ test (FDR-corrected) & $t=0.754$ & 0.459 & 0.347 & 0.064 \\
\hline e & $\begin{array}{l}\text { mGluR7 protein level in } \\
\text { whole mPFC }\end{array}$ & Age & 2 & Normal & $t$ test (FDR-corrected) & $t=1.134$ & 0.270 & 0.490 & 0.192 \\
\hline$f$ & $\begin{array}{l}\text { mGluR8 protein level in } \\
\text { whole mPFC }\end{array}$ & Age & 2 & Normal & $t$ test (FDR-corrected) & $t=-1.650$ & 0.114 & 0.698 & 0.310 \\
\hline g & $\begin{array}{l}\text { GRM1 gene expression } \\
\text { in PrL }\end{array}$ & Age & 2 & Normal & $t$ test (FDR-corrected) & $t=0.261$ & 0.798 & 0.129 & 0.058 \\
\hline h & $\begin{array}{l}\text { GRM5 gene expression } \\
\text { in PrL }\end{array}$ & Age & 2 & Normal & $t$ test (FDR-corrected) & $t=3.200$ & 0.006 & 1.515 & 0.767 \\
\hline i & $\begin{array}{l}\text { GRM2 gene expression } \\
\text { in PrL }\end{array}$ & Age & 2 & Normal & $t$ test (FDR-corrected) & $t=1.213$ & 0.243 & 0.631 & 0.209 \\
\hline j & $\begin{array}{l}\text { GRM3 gene expression } \\
\text { in PrL }\end{array}$ & Age & 2 & Normal & $t$ test (FDR-corrected) & $t=2.990$ & 0.009 & 1.593 & 0.781 \\
\hline k & $\begin{array}{l}\text { GRM4 gene expression } \\
\text { in } \operatorname{PrL}\end{array}$ & Age & 2 & Normal & $t$ test (FDR-corrected) & $t=3.058$ & 0.008 & 1.509 & 0.831 \\
\hline । & $\begin{array}{l}\text { GRM7 gene expression } \\
\text { in PrL }\end{array}$ & Age & 2 & Normal & $t$ test (FDR-corrected) & $t=1.963$ & 0.067 & 1.002 & 0.476 \\
\hline $\mathrm{m}$ & $\begin{array}{l}\text { GRM8 gene expression } \\
\text { in PrL }\end{array}$ & Age & 2 & Normal & $t$ test (FDR-corrected) & $t=1.793$ & 0.092 & 0.923 & 0.402 \\
\hline$n$ & $\begin{array}{l}\text { GRM1 gene expression } \\
\text { in IL }\end{array}$ & Age & 2 & Non-normal & $t$ test (FDR-corrected) & $t=-0.854$ & 0.406 & 0.395 & 0.103 \\
\hline ० & $\begin{array}{l}\text { GRM5 gene expression } \\
\text { in IL }\end{array}$ & Age & 2 & Normal & $t$ test (FDR-corrected) & $t=-0.046$ & 0.964 & 0.024 & 0.051 \\
\hline $\mathrm{p}$ & $\begin{array}{l}\text { GRM2 gene expression } \\
\text { in IL }\end{array}$ & Age & 2 & Normal & $t$ test (FDR-corrected) & $t=-0.228$ & 0.823 & 0.121 & 0.055 \\
\hline q & $\begin{array}{l}\text { GRM3 gene expression } \\
\text { in IL }\end{array}$ & Age & 2 & Normal & $t$ test (FDR-corrected) & $t=-0.589$ & 0.479 & 0.325 & 0.082 \\
\hline r & $\begin{array}{l}\text { GRM4 gene expression } \\
\text { in IL }\end{array}$ & Age & 2 & Normal & $t$ test (FDR-corrected) & $t=-0.682$ & 0.505 & 0.376 & 0.093 \\
\hline s & $\begin{array}{l}\text { GRM7 gene expression } \\
\text { in IL }\end{array}$ & Age & 2 & Normal & $t$ test (FDR-corrected) & $t=-0.329$ & 0.746 & 0.174 & 0.061 \\
\hline $\mathrm{t}$ & $\begin{array}{l}\text { GRM8 gene expression } \\
\text { in IL }\end{array}$ & Age & 2 & Normal & $t$ test (FDR-corrected) & $t=-0.605$ & 0.554 & 0.328 & 0.085 \\
\hline \multirow[t]{3}{*}{$\mathrm{u}$} & \multirow[t]{3}{*}{$\begin{array}{l}\text { MTEP choice accuracy } \\
\quad \text { (all doses) }\end{array}$} & Dose & 4 & Sphericity assumed & $\begin{array}{l}\text { Repeated-measures } \\
\text { ANOVA }\end{array}$ & $F=3.176$ & 0.049 & 0.364 & 0.634 \\
\hline & & Dose by delay & $4 * 7$ & Sphericity assumed & $\begin{array}{l}\text { Repeated-measures } \\
\text { ANOVA }\end{array}$ & $F=1.096$ & 0.366 & 0.154 & 0.720 \\
\hline & & Delay & 7 & Sphericity assumed & $\begin{array}{l}\text { Repeated- measures } \\
\text { ANOVA }\end{array}$ & $F=87.404$ & 0.000 & 0.936 & 1.000 \\
\hline \multirow[t]{3}{*}{ v } & \multirow[t]{3}{*}{$\begin{array}{l}\text { MTEP choice accuracy } \\
(0.1-\mu \mathrm{g} \text { dose })\end{array}$} & Dose & 2 & Sphericity assumed & $\begin{array}{l}\text { Repeated- measures } \\
\text { ANOVA }\end{array}$ & $F=2.44$ & 0.639 & 0.039 & 0.070 \\
\hline & & Dose by delay & $2 * 7$ & $\begin{array}{l}\text { Sphericity violated: Huynh-Feldt } \\
\text { corrected }\end{array}$ & $\begin{array}{l}\text { Repeated- measures } \\
\text { ANOVA }\end{array}$ & $F=0.765$ & 0.602 & 0.113 & 0.262 \\
\hline & & Delay & 7 & Sphericity assumed & $\begin{array}{l}\text { Repeated- measures } \\
\text { ANOVA }\end{array}$ & $F=56.882$ & 0.000 & 0.905 & 1.000 \\
\hline \multirow[t]{3}{*}{ w } & \multirow[t]{3}{*}{$\begin{array}{l}\text { MTEP choice accuracy } \\
\quad(0.3-\mu \mathrm{g} \text { dose })\end{array}$} & Dose & 2 & Sphericity assumed & $\begin{array}{l}\text { Repeated- measures } \\
\text { ANOVA }\end{array}$ & $F=54.178$ & 0.000 & 0.900 & 1.000 \\
\hline & & Dose by delay & $2 * 7$ & Sphericity assumed & $\begin{array}{l}\text { Repeated- measures } \\
\text { ANOVA }\end{array}$ & $F=1.388$ & 0.246 & 0.188 & 0.471 \\
\hline & & Delay & 7 & Sphericity assumed & $\begin{array}{l}\text { Repeated- measures } \\
\text { ANOVA }\end{array}$ & $F=55.700$ & 0.000 & 0.903 & 1.000 \\
\hline \multirow[t]{3}{*}{$x$} & \multirow[t]{3}{*}{$\begin{array}{l}\text { MTEP choice accuracy } \\
\quad(1.0-\mu \mathrm{g} \text { dose })\end{array}$} & Dose & 2 & Sphericity assumed & $\begin{array}{l}\text { Repeated- measures } \\
\text { ANOVA }\end{array}$ & $F=0.024$ & 0.882 & 0.004 & 0.052 \\
\hline & & Dose by delay & $2 * 7$ & Sphericity assumed & $\begin{array}{l}\text { Repeated- measures } \\
\text { ANOVA }\end{array}$ & $F=1.186$ & 0.336 & 0.165 & 0.404 \\
\hline & & Delay & 7 & $\begin{array}{l}\text { Sphericity violated: Huynh-Feldt } \\
\text { corrected }\end{array}$ & $\begin{array}{l}\text { Repeated- measures } \\
\text { ANOVA }\end{array}$ & $F=28.045$ & 0.000 & 0.824 & 1.000 \\
\hline y & MTEP Trials & Dose & 4 & Sphericity assumed & $\begin{array}{l}\text { Repeated- measures } \\
\text { ANOVA }\end{array}$ & $F=0.571$ & 0.642 & 0.087 & 0.145 \\
\hline \multirow[t]{2}{*}{ z } & $\begin{array}{l}\text { MTEP response latency } \\
\text { (matching phase) }\end{array}$ & Dose & 4 & Sphericity assumed & $\begin{array}{l}\text { Repeated- measures } \\
\text { ANOVA }\end{array}$ & $F=2.550$ & 0.088 & 0.298 & 0.531 \\
\hline & \multicolumn{9}{|c|}{ (Continued) } \\
\hline
\end{tabular}


Table 6. Continued

\begin{tabular}{|c|c|c|c|c|c|c|c|c|c|}
\hline & Measure & Factor(s) & Level(s) & $\begin{array}{l}\text { Data structure: normality tests } \\
\text { Kolmogorov-Smirnov } \\
\text { ( } t \text { test); } \\
\text { Mauchly's sphericity (ANOVAs) }\end{array}$ & Type of test & $\begin{array}{l}\text { Statistical } \\
\text { value }\end{array}$ & $p$ value & $\begin{array}{l}\text { Effect size: } \\
\text { Cohen's } d \text { ( } t \text { test); } \\
\text { partial } \eta^{2} \\
\text { (ANOVA) }\end{array}$ & $\begin{array}{l}\text { Observed } \\
\text { power }\end{array}$ \\
\hline$\overline{a a}$ & $\begin{array}{l}\text { MTEP response latency } \\
\text { (sample phase) }\end{array}$ & Dose & 4 & Sphericity assumed & $\begin{array}{l}\text { Repeated- measures } \\
\text { ANOVA }\end{array}$ & $F=1.149$ & 0.356 & 0.161 & 0.257 \\
\hline bb & $\begin{array}{l}\text { MTEP carry-over } \\
\text { effects (washout } \\
\text { days, all doses) }\end{array}$ & Day & 4 & Sphericity assumed & $\begin{array}{l}\text { Repeated- measures } \\
\text { ANOVA }\end{array}$ & $F=0.239$ & 0.868 & 0.038 & 0.087 \\
\hline cc & $\begin{array}{l}\text { MTEP injections (all } \\
\text { doses) }\end{array}$ & Injection & 4 & $\begin{array}{l}\text { Sphericity violated: Huynh-Feldt } \\
\text { corrected }\end{array}$ & $\begin{array}{l}\text { Repeated- measures } \\
\text { ANOVA }\end{array}$ & $F=1.205$ & 0.334 & 0.167 & 0.269 \\
\hline \multirow[t]{3}{*}{ dd } & \multirow[t]{3}{*}{$\begin{array}{l}\text { LY341495 choice } \\
\text { accuracy (all doses) }\end{array}$} & Dose & 4 & Sphericity assumed & $\begin{array}{l}\text { Repeated- measures } \\
\text { ANOVA }\end{array}$ & $F=4.778$ & 0.008 & 0.347 & 0.853 \\
\hline & & Dose by delay & $4 * 7$ & Sphericity assumed & $\begin{array}{l}\text { Repeated- measures } \\
\text { ANOVA }\end{array}$ & $F=2.083$ & 0.009 & 0.188 & 0.978 \\
\hline & & Delay & 7 & $\begin{array}{l}\text { Sphericity violated: Huynh-Feldt } \\
\text { corrected }\end{array}$ & $\begin{array}{l}\text { Repeated- measures } \\
\text { ANOVA }\end{array}$ & $F=49.091$ & 0.000 & 0.845 & 1.000 \\
\hline \multirow[t]{3}{*}{ ee } & \multirow{3}{*}{$\begin{array}{l}\text { LY341495 choice } \\
\text { accuracy (5-ng } \\
\text { dose) }\end{array}$} & Dose & 2 & Sphericity assumed & $\begin{array}{l}\text { Repeated- measures } \\
\text { ANOVA }\end{array}$ & $F=0.570$ & 0.470 & 0.060 & 0.104 \\
\hline & & Dose by delay & $2 * 7$ & Sphericity assumed & $\begin{array}{l}\text { Repeated- measures } \\
\text { ANOVA }\end{array}$ & $F=2.834$ & 0.018 & 0.239 & 0.847 \\
\hline & & Delay & 7 & $\begin{array}{l}\text { Sphericity violated: Huynh-Feldt } \\
\text { corrected }\end{array}$ & $\begin{array}{l}\text { Repeated- measures } \\
\text { ANOVA }\end{array}$ & $F=29.521$ & 0.000 & 0.766 & 1.000 \\
\hline \multirow[t]{3}{*}{$\mathrm{ff}$} & \multirow{3}{*}{$\begin{array}{l}\text { LY341495 choice } \\
\text { accuracy (50-ng } \\
\text { dose) }\end{array}$} & Dose & 2 & Sphericity assumed & $\begin{array}{l}\text { Repeated- measures } \\
\text { ANOVA }\end{array}$ & $F=1.895$ & 0.202 & 0.174 & 0.234 \\
\hline & & Dose by delay & $2 * 7$ & $\begin{array}{l}\text { Sphericity violated: Huynh-Feldt } \\
\text { corrected }\end{array}$ & $\begin{array}{l}\text { Repeated- measures } \\
\text { ANOVA }\end{array}$ & $F=2.887$ & 0.029 & 0.243 & 0.855 \\
\hline & & Delay & 7 & $\begin{array}{l}\text { Sphericity violated: Huynh-Feldt } \\
\text { corrected }\end{array}$ & $\begin{array}{l}\text { Repeated- measures } \\
\text { ANOVA }\end{array}$ & $F=41.188$ & 0.000 & 0.821 & 1.000 \\
\hline \multirow[t]{3}{*}{ gg } & \multirow{3}{*}{$\begin{array}{l}\text { LY341495 choice } \\
\text { accuracy (500-ng } \\
\text { dose) }\end{array}$} & Dose & 2 & Sphericity assumed & $\begin{array}{l}\text { Repeated- measures } \\
\text { ANOVA }\end{array}$ & $F=14.911$ & 0.004 & 0.624 & 0.929 \\
\hline & & Dose by delay & $2 * 7$ & Sphericity assumed & $\begin{array}{l}\text { Repeated- measures } \\
\text { ANOVA }\end{array}$ & $F=1.793$ & 0.118 & 0.166 & 0.623 \\
\hline & & Delay & 7 & $\begin{array}{l}\text { Sphericity violated: Huynh-Feldt } \\
\text { corrected }\end{array}$ & $\begin{array}{l}\text { Repeated- measures } \\
\text { ANOVA }\end{array}$ & $F=37.902$ & 0.000 & 0.808 & 1.000 \\
\hline hh & $\begin{array}{l}\text { LY341495 choice } \\
\text { accuracy (0-s delay) }\end{array}$ & Dose & 4 & $\begin{array}{l}\text { Sphericity violated: Huynh-Feldt } \\
\text { corrected }\end{array}$ & $\begin{array}{l}\text { Repeated- measures } \\
\text { ANOVA }\end{array}$ & $F=0.617$ & 0.512 & 0.064 & 0.124 \\
\hline ii & $\begin{array}{l}\text { LY341495 choice } \\
\text { accuracy (2-s delay) }\end{array}$ & Dose & 4 & Sphericity assumed & $\begin{array}{l}\text { Repeated- measures } \\
\text { ANOVA }\end{array}$ & $F=0.527$ & 0.668 & 0.055 & 0.143 \\
\hline jj & $\begin{array}{l}\text { LY341495 choice } \\
\text { accuracy (4-s delay) }\end{array}$ & Dose & 4 & Sphericity assumed & $\begin{array}{l}\text { Repeated- measures } \\
\text { ANOVA }\end{array}$ & $F=0.267$ & 0.848 & 0.029 & 0.094 \\
\hline kk & $\begin{array}{l}\text { LY341495 choice } \\
\text { accuracy (8-s delay) }\end{array}$ & Dose & 4 & Sphericity assumed & $\begin{array}{l}\text { Repeated- measures } \\
\text { ANOVA }\end{array}$ & $F=2.239$ & 0.107 & 0.199 & 0.504 \\
\hline ॥ & $\begin{array}{l}\text { LY341495 choice } \\
\text { accuracy (12-s } \\
\text { delay) }\end{array}$ & Dose & 4 & Sphericity assumed & $\begin{array}{l}\text { Repeated- measures } \\
\text { ANOVA }\end{array}$ & $F=2.911$ & 0.053 & 0.244 & 0.627 \\
\hline \multirow[t]{4}{*}{$\mathrm{mm}$} & \multirow{4}{*}{$\begin{array}{l}\text { LY341495 choice } \\
\text { accuracy (18-s } \\
\text { delay) }\end{array}$} & Dose (all doses) & 4 & Sphericity assumed & $\begin{array}{l}\text { Repeated- measures } \\
\text { ANOVA }\end{array}$ & $F=5.009$ & 0.007 & 0.358 & 0.870 \\
\hline & & Dose (Veh vs 5 ng) & 2 & Normal & $\begin{array}{l}\text { Post hoc paired-samples } \\
\qquad \begin{array}{l}\text { t test } \\
\text { (Dunnett-corrected) }\end{array}\end{array}$ & $t=2.501$ & 0.034 & 0.945 & 0.260 \\
\hline & & Dose (Veh vs 50 ng) & 2 & Normal & $\begin{array}{l}\text { Post hoc paired-samples } \\
\quad t \text { test } \\
\text { (Dunnett-corrected) }\end{array}$ & $t=3.212$ & 0.011 & 0.956 & 0.265 \\
\hline & & $\begin{array}{l}\text { Dose (Veh vs } 500 \\
\text { ng) }\end{array}$ & 2 & Normal & $\begin{array}{l}\text { Post hoc paired-samples } \\
\qquad t \text { test } \\
\text { (Dunnett-corrected) }\end{array}$ & $t=2.596$ & 0.029 & 1.069 & 0.318 \\
\hline \multirow[t]{4}{*}{$\mathrm{nn}$} & \multirow{4}{*}{$\begin{array}{l}\text { LY341495 choice } \\
\text { accuracy ( } 24-s \\
\text { delay) }\end{array}$} & Dose (all doses) & 4 & Sphericity assumed & $\begin{array}{l}\text { Repeated- measures } \\
\text { ANOVA }\end{array}$ & $F=3.57$ & 0.027 & 0.284 & 0.725 \\
\hline & & Dose (Veh vs 5 ng) & 2 & Normal & $\begin{array}{l}\text { Post hoc paired-samples } \\
\quad t \text { test } \\
\text { (Dunnett-corrected) }\end{array}$ & $t=-1.041$ & 0.325 & 0.364 & 0.073 \\
\hline & & Dose (Veh vs $50 \mathrm{ng}$ ) & 2 & Normal & $\begin{array}{l}\text { Post hoc paired-samples } \\
\quad t \text { test } \\
\text { (Dunnett-corrected) }\end{array}$ & $t=-0.347$ & 0.736 & 0.146 & 0.039 \\
\hline & & $\begin{array}{l}\text { Dose (Veh vs } 500 \\
\text { ng) }\end{array}$ & 2 & Normal & $\begin{array}{l}\text { Post hoc paired-samples } \\
\quad t \text { test } \\
\text { (Dunnett-corrected) }\end{array}$ & $t=2.402$ & 0.040 & 0.778 & 0.190 \\
\hline ০० & LY341495 trials & Dose & 4 & Sphericity assumed & $\begin{array}{l}\text { Repeated- measures } \\
\text { ANOVA }\end{array}$ & $F=2.422$ & 0.088 & 0.212 & 0.540 \\
\hline $\mathrm{pp}$ & $\begin{array}{l}\text { LY341495 response } \\
\text { latency (matching } \\
\text { phase) }\end{array}$ & Dose & 4 & Sphericity assumed & $\begin{array}{l}\text { Repeated- measures } \\
\text { ANOVA }\end{array}$ & $F=1.000$ & 0.408 & 0.100 & 0.242 \\
\hline
\end{tabular}


Table 6. Continued

\begin{tabular}{|c|c|c|c|c|c|c|c|c|c|}
\hline & Measure & Factor(s) & Level(s) & $\begin{array}{l}\text { Data structure: normality tests } \\
\text { Kolmogorov-Smirnov } \\
\text { ( } t \text { test); } \\
\text { Mauchly's sphericity (ANOVAs) }\end{array}$ & Type of test & $\begin{array}{l}\text { Statistical } \\
\text { value }\end{array}$ & $p$ value & $\begin{array}{l}\text { Effect size: } \\
\text { Cohen's } d \text { ( } t \text { test); } \\
\text { partial } \eta^{2} \\
\text { (ANOVA) }\end{array}$ & $\begin{array}{l}\text { Observed } \\
\text { power }\end{array}$ \\
\hline qq & $\begin{array}{l}\text { LY341495 response } \\
\text { latency (sample } \\
\text { phase) }\end{array}$ & Dose & 4 & $\begin{array}{l}\text { Sphericity violated: Huynh-Feldt } \\
\text { corrected }\end{array}$ & $\begin{array}{l}\text { Repeated- measures } \\
\text { ANOVA }\end{array}$ & $F=2.017$ & 0.185 & 0.183 & 0.460 \\
\hline $\mathrm{rr}$ & $\begin{array}{l}\text { LY341495 Carry-over } \\
\text { effects (washout } \\
\text { days, all doses) }\end{array}$ & Day & 4 & Sphericity assumed & $\begin{array}{l}\text { Repeated- measures } \\
\text { ANOVA }\end{array}$ & $F=1.341$ & 0.282 & 0.130 & 0.316 \\
\hline ss & $\begin{array}{l}\text { LY341495 injections (all } \\
\text { doses) }\end{array}$ & Injection & 4 & Sphericity assumed & $\begin{array}{l}\text { Repeated- measures } \\
\text { ANOVA }\end{array}$ & $F=0.276$ & 0.842 & 0.030 & 0.096 \\
\hline
\end{tabular}

et al., 2011; Gilmartin et al., 2013; Kim et al., 2016; Levin et al., 2017).

In addition to GRM3 and GRM5, the analysis of mRNA expression also revealed a reliable age-related reduction in GRM4 in PrL, although mPFC mGluR4 protein expression did not differ as a function of age. While implicated in psychiatric disorders (Woźniak et al., 2016; Isherwood et al., 2017), learning and memory (Davis et al., 2013; Iscru et al., 2013), and neurodegenerative disease (Niswender et al., 2016), the role of GRM4 in cognition is not well understood. Ligands targeting mGluR4 are currently unavailable, but important future work includes the exploration of this receptor in relation to working memory and other PFC-mediated cognitive functions in aging and disease states.

\section{Selective blockade of mGluR5 and mGluR2/3 impairs working memory performance}

The second major finding of this study is that mGluRs in the PrL contribute to optimal working memory function. The few previous studies using systemic administration of mGluR5- or mGluR2/3-directed ligands have produced varied conclusions regarding the contributions of these receptors to working memory (Aultman and Moghaddam, 2001; Campbell et al., 2004; Homayoun et al., 2004; Novitskaya et al., 2010). Although these receptors are highly expressed in the PFC, systemic drug administration cannot isolate the contribution of PFC mGluRs to working memory as they are also present in other brain regions that contribute to diverse aspects of cognition (Ferraguti and Shigemoto, 2006; Gravius et al., 2010). To determine whether signaling via mGluRs in the mPFC, and more specifically the PrL, is necessary for working memory, we investigated the effects of micro-infusing subtypeselective antagonists into the PrL during delayed response task performance.

In the current study, the highly selective mGluR5 antagonist MTEP impaired delayed response accuracy without influencing non-mnemonic aspects of performance (number of trials completed or response latencies). The fact that this impairment, as well as that induced by mGluR $2 / 3$ blockade, was delay-dependent is consistent with the interpretation that mGluR blockade in mPFC specifically impaired working memory. While rats can use mediating strategies that circumvent mnemonic demands on delayed response tasks (e.g., leaning their body toward the correct lever while nose poking in the food trough; Herremans et al., 1996; Chudasama and Muir, 1997), such strategies would not be expected to produce a robust pattern of declining accuracy with increasing delays. In fact, this pattern of declining accuracy with increasing delays is reliably observed, even under baseline conditions (Beas et al., 2013; Bañuelos et al., 2014; McQuail et al., 2016; Hernandez et al., 2017).

The importance of mGluR5 to working memory may relate to its ability to increase excitability and firing of mPFC pyramidal neurons in response to synaptic stimulation (Homayoun and Moghaddam, 2006; Lecourtier et al., 2007; Sidiropoulou et al., 2009). Specifically, sustained activity of neurons in the PFC during delays interposed between stimulus perception and response initiation is widely considered to be the physiologic basis for temporary storage of information in working memory (Goldman-Rakic, 1995). Ionotropic NMDARs are essential for persistent firing and working memory (Wang et al., 2013; McQuail et al., 2016) and mGluR5 may support these processes by potentiating NMDAR currents (Mannaioni et al., 2001). Consistent with the view that mGluR5 exerts its effects on working memory via interactions with NMDARs are data showing that mGluR5 blockade exacerbates working memory impairments induced by NMDAR antagonists, including phencyclidine (PCP) and MK-801 (Campbell et al., 2004; Homayoun et al., 2004). Diminished contributions from mGluR5, as in normal aging or following pharmacological blockade, may shift glutamate signaling toward preserved binding sites on mGluR1 that stimulate postsynaptic changes that are less advantageous to working memory. Specifically, mGluR1 stimulates release of $\mathrm{Ca}^{2+}$ from intracellular stores (Mannaioni et al., 2001), and such mGluR-mediated mobilization of intracellular $\mathrm{Ca}^{2+}$ is associated with mixed effects on PFC neuron excitability (Hagenston et al., 2008). Indeed, aged pyramidal neurons release more $\mathrm{Ca}^{2+}$ from intracellular stores than neurons from young adults after stimulation with an agonist of Group I mGluRs (McQuail et al., 2013). Therefore, impaired Group I mGluR function may reflect not only diminished contributions from mGluR5 that support PFC neural function and working memory via NMDARs, but also a relative strengthening of contributions from mGluR1 linked to intracellular $\mathrm{Ca}^{2+}$ signaling that disrupts working memory (Arnsten et al., 2012).

One prior study that assessed the effects of intra-PFC administration of mGluR ligands on working memory found that the mGluR2/3 agonist APDC dose-dependently impaired performance in rats performing a T-maze working memory task, whereas the mGluR2/3 antagonist LY341495 had no effect (Gregory et al., 2003). In contrast, the results 
of the current study showed that intra-PrL LY341495 impaired working memory accuracy, in the absence of effects on non-mnemonic aspects of task performance. The reasons for this apparent discrepancy between the two studies are unclear, although there were considerable methodological differences between the current study and that of Gregory et al. (2003). For example, the T-maze task employed by Gregory et al. (2003) likely engages medial temporal lobe mnemonic systems in addition to mPFC. Moreover, the target of mPFC infusions in that study may not have been restricted to the PrL subregion of $\mathrm{mPFC}$ as in the current report. Although additional studies in rats are needed to clarify the discrepancies between these two studies, it is notable that the current findings are in agreement with recent work by Jin et al. (2017), which assessed the effects of mGluR2/3 agonists in a nonhuman primate working memory task and in a rodent T-maze spatial working memory task. These authors reported that low doses of mGluR2/3 agonists enhanced both behavior (in primates and rodents) and PFC electrophysiological signatures of working memory (in primates; Jin et al., 2017). In the context of the current findings, blocking glutamate signaling via mGluR2/3 may impair working memory by altering regulation of extracellular glutamate levels, reducing modulation of ion channels in dendritic spines, or both. mGluR2/3 localizes to presynaptic terminals and glial processes where it regulates extracellular glutamate by inhibition of synaptic release (Tanabe et al., 1993; Muly et al., 2007) or stimulation of glutamate transporters on glial processes (Aronica et al., 2003; Corti et al., 2007). Indeed, presynaptic/glial mGluR2/3 is a prime target to counter dysregulated PFC glutamate signaling observed in schizophrenia (Patil et al., 2007; Moghaddam and Javitt, 2012; Vinson and Conn, 2012). Drugs that produce pathologically elevated release of glutamate and asynchronous PFC neural activity, including ketamine, PCP, and MK-801, are used widely to experimentally induce schizophrenia-like impairments in animal models, which are normalized by mGluR2/3 agonists (Moghaddam et al., 1997; Moghaddam and Adams, 1998; Lorrain et al., 2003; Jackson et al., 2004; Homayoun et al., 2005; Benneyworth et al., 2007; for review, see Maksymetz et al., 2017). Blocking mGluR2/3 recapitulates the excess extracellular glutamate produced by NMDAR antagonists which can, in turn, impair working memory (Dietrich et al., 2002; Xi et al., 2002). Parallel to regulation of extracellular glutamate are contributions from mGluR2/3 on dendritic spines that modulate PFC neural excitability via influences on postsynaptic ion channels. Activation of mGluR2/3 opposes cAMP-PKA signaling in PFC neurons that reduces persistent firing and impairs working memory (Ramos et al., 2006; Wang et al., 2007; for review, see Arnsten et al., 2005, 2012). A recent series of studies determined that inhibiting cAMP-PKA signaling through activation of postsynaptic mGluRs with either a mixed mGluR2/3 agonist or a selective mGluR3 agonist is sufficient to enhance persistent PFC neuronal firing during performance of a working memory task (Jin et al., 2017, 2018). Also relevant to actions in postsynaptic spines is the capacity of mGluR2/3 to potentiate NMDAR function. Stim- ulation of mGluR2/3 in dissociated mPFC pyramidal neurons potentiates NMDAR currents, especially in those NMDAR complexes that contain an NR2A subunit (Tyszkiewicz et al., 2004). The latter finding is highly consequential to working memory as previous work from our lab has determined that glutamate signaling via NR2A-NMDARs, and not NR2BNMDARs, is essential for working memory (McQuail et al., 2016). Furthermore, loss of NR2A, but not NR2B, in the $\mathrm{mPFC}$ is correlated with severity of working memory impairment in aging (McQuail et al., 2016). When viewed together, these data suggest that loss of mGluR2/3, or possibly only mGluR3, can induce impaired regulation of glutamate signaling at both pre- and postsynaptic locations and, further, may exacerbate NMDAR-mediated deficits that arise with aging or in neuropsychiatric disease.

\section{Possible therapeutic benefits of targeting mGluRs 5 and $2 / 3$}

Selective blockade of mGluR5 or mGluR2/3 in young PrL recapitulates the age-related working memory impairments that are reliably observed across species (OscarBerman and Bonner, 1985; Dunnett et al., 1988; Rapp and Amaral, 1989; Bachevalier et al., 1991; Lamar and Resnick, 2004; Beas et al., 2013; Bañuelos et al., 2014; McQuail et al., 2016; Hernandez et al., 2017). In these studies, aged subjects perform comparably to their young counterparts at short delays but are disproportionately impaired relative to young as the delay over which they must maintain information increases. The loss of mGluR5 and mGluR2/3 from the aged mPFC and their necessity for working memory has important implications for the treatment of cognitive impairments that accompany normal aging. Contemporaneous with decline of mGluRs, loss of NMDARs in the PFC is also an established feature of normal aging linked to working memory decline (Piggott et al., 1992; Mitchell and Anderson, 1998; Bai et al., 2004; Magnusson et al., 2005; Das and Magnusson, 2008; McQuail et al., 2016). Given their functional interactions, we can speculate that age-related changes to ionotropic and mGluRs are interdependent features of dysregulated glutamate signaling contributing to age-related cognitive impairments. Strategies that target NMDARs yield, at best, moderate rescue of cognitive impairment in aged individuals (Baxter et al., 1994; Billard and Rouaud, 2007; Burgdorf et al., 2011; Panizzutti et al., 2014; McQuail et al., 2016). A shortcoming of NMDAR-directed treatments may be a failure to address concurrent age-related loss of mGluRs, which synergistically support glutamate signaling required for optimal working memory. Consequently, treatments that potentiate glutamate signaling via mGluR5 or mGluR2/3 separately or in concert with NMDAR-directed ligands are promising candidates to reverse age-related impairment of PFC-dependent cognition. Previous work showing positive effects of mGluR2/3 or mGluR3 agonists on PFC neural function and working memory, along with similar evidence from mGluR5 agonists, provides promising preliminary support for the notion that these receptors are viable therapeutic targets that can be leveraged to improve cognition (Ayala et al., 2009; Cleva and Olive, 2011; Jin et al., $2017,2018)$. An important avenue of future research, how- 
ever, will be determining whether modulation of mGluRs that enhances cognition in young adults can reverse cognitive impairments caused by changes to glutamate signaling in the aged brain.

\section{References}

Anderson JJ, Rao SP, Rowe B, Giracello DR, Holtz G, Chapman DF, Tehrani L, Bradbury MJ, Cosford NDP, Varney MA (2002) [3H]methoxymethyl-3-[(2-methyl-1,3-thiazol-4-yl)ethynyl]pyridine binding to metabotropic glutamate receptor subtype 5 in rodent brain: in vitro and in vivo characterization. J Pharmacol Exp Ther 303:1044-1051. CrossRef

Arnsten AFT, Ramos BP, Birnbaum SG, Taylor JR (2005) Protein kinase $A$ as a therapeutic target for memory disorders: rationale and challenges. Trends Mol Med 11:121-128. CrossRef Medline

Arnsten AFT, Wang MJ, Paspalas CD (2012) Neuromodulation of thought: flexibilities and vulnerabilities in prefrontal cortical network synapses. Neuron 76:223-239. CrossRef Medline

Aronica E, Gorter JA, ljlst-Keizers H, Rozemuller AJ, Yankaya B, Leenstra S, Troost D (2003) Expression and functional role of mGluR3 and mGluR5 in human astrocytes and glioma cells: opposite regulation of glutamate transporter proteins. Eur J Neurosci 17:2106-2118. Medline

Aultman JM, Moghaddam B (2001) Distinct contributions of glutamate and dopamine receptors to temporal aspects of rodent working memory using a clinically relevant task. Psychopharmacology (Berl) 153:353-364. Medline

Ayala JE, Chen Y, Banko JL, Sheffler DJ, Williams R, Telk AN, Watson NL, Xiang Z, Zhang Y, Jones PJ, Lindsley CW, Olive MF, Conn PJ (2009) mGluR5 positive allosteric modulators facilitate both hippocampal LTP and LTD and enhance spatial learning. Neuropsychopharmacology 34:2057-2071. CrossRef Medline

Bachevalier J, Landis LS, Walker LC, Brickson M, Mishkin M, Price DL, Cork LC (1991) Aged monkeys exhibit behavioral deficits indicative of widespread cerebral dysfunction. Neurobiol Aging 12:99-111. Medline

Baddeley AD (1986) Working memory. New York: Clarendon Press; Oxford University Press.

Bai L, Hof PR, Standaert DG, Xing Y, Nelson SE, Young AB, Magnusson KR (2004) Changes in the expression of the NR2B subunit during aging in macaque monkeys. Neurobiol Aging 25:201-208. Medline

Bañuelos C, Beas BS, McQuail JA, Gilbert RJ, Frazier CJ, Setlow B, Bizon JL (2014) Prefrontal cortical GABAergic dysfunction contributes to age-related working memory impairment. J Neurosci 34: 3457-3466. CrossRef

Baxter MG, Lanthorn TH, Frick KM, Golski S, Wan RQ, Olton DS (1994) D-cycloserine, a novel cognitive enhancer, improves spatial memory in aged rats. Neurobiol Aging 15:207-213. Medline

Beas BS, Setlow B, Bizon JL (2013) Distinct manifestations of executive dysfunction in aged rats. Neurobiol Aging 34:2164-2174. CrossRef Medline

Benjamini Y, Hochberg Y (1995) Controlling the false discovery rate: a practical and powerful approach to multiple testing. J R Stat Soc Ser B Methodol 57:289-300.

Benneyworth MA, Xiang Z, Smith RL, Garcia EE, Conn PJ, SandersBush E (2007) A Selective positive allosteric modulator of metabotropic glutamate receptor subtype 2 blocks a hallucinogenic drug model of psychosis. Mol Pharmacol 72:477-484. CrossRef Medline

Billard J-M, Rouaud E (2007) Deficit of NMDA receptor activation in CA1 hippocampal area of aged rats is rescued by D-cycloserine. Eur J Neurosci 25:2260-2268. CrossRef Medline

Bishop JR, Ellingrod VL (2007) Metabotropic glutamate receptor genes as candidates for pharmacogenetic studies of current and future antipsychotic agents in schizophrenia. Curr Pharmacogenomics 5:21-30. CrossRef

Bjarnadóttir TK, Gloriam DE, Hellstrand SH, Kristiansson $\mathrm{H}$, Fredriksson R, Schiöth HB (2006) Comprehensive repertoire and phylogenetic analysis of the $G$ protein-coupled receptors in human and mouse. Genomics 88:263-273. CrossRef

Burgdorf J, Zhang X, Weiss C, Matthews E, Disterhoft JF, Stanton PK, Moskal JR (2011) The N-methyl-d-aspartate receptor modulator GLYX-13 enhances learning and memory, in young adult and learning impaired aging rats. Neurobiol Aging 32:698-706. CrossRef Medline

Busse CS, Brodkin J, Tattersall D, Anderson JJ, Warren N, Tehrani L, Bristow LJ, Varney MA, Cosford NDP (2004) The behavioral profile of the potent and selective mGlu5 receptor antagonist 3-[(2methyl-1,3-thiazol-4-yl)ethynyl]pyridine (MTEP) in rodent models of anxiety. Neuropsychopharmacol 29:1971-1979. CrossRef

Campbell UC, Lalwani K, Hernandez L, Kinney GG, Conn PJ, Bristow LJ (2004) The mGluR5 antagonist 2-methyl-6-(phenylethynyl)pyridine (MPEP) potentiates PCP-induced cognitive deficits in rats. Psychopharmacology (Berl) 175:310-318. CrossRef Medline Cassaday HJ, Nelson AJD, Pezze MA (2014) From attention to memory along the dorsal-ventral axis of the medial prefrontal cortex: some methodological considerations. Front Syst Neurosci 8:160. CrossRef

Chudasama Y, Muir JL (1997) A behavioural analysis of the delayed non-matching to position task: the effects of scopolamine, lesions of the fornix and of the prelimbic region on mediating behaviours by rats. Psychopharmacology (Berl) 134:73-82. Medline

Cleva RM, Olive MF (2011) Positive allosteric modulators of type 5 metabotropic glutamate receptors (mGluR5) and their therapeutic potential for the treatment of CNS disorders. Molecules 16:20972106. CrossRef Medline

Corti C, Battaglia G, Molinaro G, Riozzi B, Pittaluga A, Corsi M, Mugnaini M, Nicoletti F, Bruno V (2007) The use of knock-out mice unravels distinct roles for mGlu2 and mGlu3 metabotropic glutamate receptors in mechanisms of neurodegeneration/neuroprotection. J Neurosci 27:8297-8308. CrossRef Medline

Corti C, Xuereb JH, Crepaldi L, Corsi M, Michielin F, Ferraguti F (2011) Altered levels of glutamatergic receptors and $\mathrm{Na}+/ \mathrm{K}+$ ATPase- $\alpha 1$ in the prefrontal cortex of subjects with schizophrenia. Schizophr Res 128:7-14. CrossRef Medline

Crook JM, Akil M, Law BCW, Hyde TM, Kleinman JE (2002) Comparative analysis of group II metabotropic glutamate receptor immunoreactivity in Brodmann's area 46 of the dorsolateral prefrontal cortex from patients with schizophrenia and normal subjects. Mol Psychiatry 7:157-164. CrossRef

Das SR, Magnusson KR (2008) Relationship between mRNA expression of splice forms of the zeta1 subunit of the N-methyl-Daspartate receptor and spatial memory in aged mice. Brain Res 1207:142-154. CrossRef Medline

Davis MJ, lancu OD, Acher FC, Stewart BM, Eiwaz MA, Duvoisin RM, Raber J (2013) Role of mGluR4 in acquisition of fear learning and memory. Neuropharmacology 66:365-372. CrossRef Medline

Deschwanden A, Karolewicz B, Feyissa AM, Treyer V, Ametamey SM, Johayem A, Burger C, Auberson YP, Sovago J, Stockmeier CA, Buck A, Hasler G (2011) Reduced metabotropic glutamate receptor 5 density in major depression determined by [11C]ABP688 positron emission tomography and postmortem study. Am J Psychiatry 168:727-734. CrossRef Medline

Dietrich D, Kral T, Clusmann H, Friedl M, Schramm J (2002) Presynaptic group II metabotropic glutamate receptors reduce stimulated and spontaneous transmitter release in human dentate gyrus. Neuropharmacology 42:297-305. Medline

Dunnett SB, Evenden JL, Iversen SD (1988) Delay-dependent shortterm memory deficits in aged rats. Psychopharmacology (Berl) 96:174-180. Medline

Ferraguti F, Shigemoto R (2006) Metabotropic glutamate receptors. Cell Tissue Res 326:483-504. CrossRef Medline

Frank E, Newell KA, Huang X-F (2011) Density of metabotropic glutamate receptors 2 and 3 (mGluR2/3) in the dorsolateral prefrontal cortex does not differ with schizophrenia diagnosis but decreases with age. Schizophr Res 128:56-60. CrossRef

Ghose S, Gleason KA, Potts BW, Lewis-Amezcua K, Tamminga CA (2009) Differential expression of metabotropic glutamate receptors 
2 and 3 in schizophrenia: a mechanism for antipsychotic drug action? Am J Psychiatry 166:812-820. CrossRef Medline

Gilmartin MR, Miyawaki H, Helmstetter FJ, Diba K (2013) Prefrontal activity links nonoverlapping events in memory. J Neurosci 33: 10910-10914. CrossRef Medline

Goldman-Rakic PS (1995) Cellular basis of working memory. Neuron 14:477-485. Medline

Goldman-Rakic PS (1996) Regional and cellular fractionation of working memory. Proc Natl Acad Sci USA 93:13473-13480. Medline

Gravius A, Pietraszek M, Dekundy A, Danysz W (2010) Metabotropic glutamate receptors as therapeutic targets for cognitive disorders. Curr Top Med Chem 10:187-206. Medline

Gregory ML, Stech NE, Owens RW, Kalivas PW (2003) Prefrontal group II metabotropic glutamate receptor activation decreases performance on a working memory task. Ann NY Acad Sci 1003: 405-409. Medline

Hagenston AM, Fitzpatrick JS, Yeckel MF (2008) MGluR-mediated calcium waves that invade the soma regulate firing in layer $\mathrm{V}$ medial prefrontal cortical pyramidal neurons. Cereb Cortex 18: 407-423. CrossRef

Hernandez CM, Vetere LM, Orsini CA, McQuail JA, Maurer AP, Burke SN, Setlow B, Bizon JL (2017) Decline of prefrontal corticalmediated executive functions but attenuated delay discounting in aged Fischer $344 \times$ brown Norway hybrid rats. Neurobiol Aging 60:141-152. CrossRef Medline

Herremans AHJ, Hijzen TH, Welborn PFE, Olivier B, Slangen JL (1996) Effects of infusion of cholinergic drugs into the prefrontal cortex area on delayed matching to position performance in the rat. Brain Res 711:102-111. Medline

Homayoun H, Jackson ME, Moghaddam B (2005) Activation of metabotropic glutamate $2 / 3$ receptors reverses the effects of NMDA receptor hypofunction on prefrontal cortex unit activity in awake rats. J Neurophysiol 93:1989-2001. CrossRef Medline

Homayoun H, Moghaddam B (2006) Bursting of prefrontal cortex neurons in awake rats is regulated by metabotropic glutamate 5 (mGlu5) receptors: rate-dependent influence and interaction with NMDA receptors. Cereb Cortex 16:93-105. CrossRef Medline

Homayoun H, Stefani MR, Adams BW, Tamagan GD, Moghaddam B (2004) Functional interaction between NMDA and mGlu5 receptors: effects on working memory, instrumental learning, motor behaviors, and dopamine release. Neuropsychopharmacology 29: 1259-1269. CrossRef Medline

Iscru E, Goddyn H, Ahmed T, Callaerts-Vegh Z, D'Hooge R, Balschun D (2013) Improved spatial learning is associated with increased hippocampal but not prefrontal long-term potentiation in mGluR4 knockout mice. Genes Brain Behav 12:615-625. CrossRef

Isherwood SN, Robbins TW, Nicholson JR, Dalley JW, Pekcec A (2017) Selective and interactive effects of D2 receptor antagonism and positive allosteric mGluR4 modulation on waiting impulsivity. Neuropharmacology 123:249-260. CrossRef Medline

Jackson ME, Homayoun H, Moghaddam B (2004) NMDA receptor hypofunction produces concomitant firing rate potentiation and burst activity reduction in the prefrontal cortex. Proc Natl Acad Sci USA 101:8467-8472. CrossRef Medline

Jin LE, Wang M, Yang S-T, Yang Y, Galvin VC, Lightbourne TC, Ottenheimer D, Zhong Q, Stein J, Raja A, Paspalas CD, Arnsten AFT (2017) mGluR2/3 mechanisms in primate dorsolateral prefrontal cortex: evidence for both presynaptic and postsynaptic actions. Mol Psychiatry 22:1615-1625. CrossRef Medline

Jin LE, Wang M, Galvin VC, Lightbourne TC, Conn PJ, Arnsten AFT, Paspalas CD (2018) mGluR2 versus mGluR3 metabotropic glutamate receptors in primate dorsolateral prefrontal cortex: postsynaptic mGluR3 strengthen working memory networks. Cereb Cortex 28:974-987. CrossRef Medline

Kim D, Jeong H, Lee J, Ghim J-W, Her ES, Lee S-H, Jung MW (2016) Distinct roles of parvalbumin- and somatostatin-expressing interneurons in working memory. Neuron 92:902-915. CrossRef Medline
Kingston $A E$, Ornstein PL, Wright RA, Johnson BG, Mayne NG, Burnett JP, Belagaje R, Wu S, Schoepp DD (1998) LY341495 is a nanomolar potent and selective antagonist of group II metabotropic glutamate receptors. Neuropharmacology 37:1-12. Medline

Lamar M, Resnick SM (2004) Aging and prefrontal functions: dissociating orbitofrontal and dorsolateral abilities. Neurobiol Aging 25:553-558. CrossRef Medline

Lecourtier L, Homayoun H, Tamagnan G, Moghaddam B (2007) Positive allosteric modulation of metabotropic glutamate 5 (mGlu5) receptors reverses N-Methyl-D-aspartate antagonist-induced alteration of neuronal firing in prefrontal cortex. Biol Psychiatry 62:739-746. CrossRef Medline

Levin N, Kritman M, Maroun M, Akirav I (2017) Differential roles of the infralimbic and prelimbic areas of the prefrontal cortex in reconsolidation of a traumatic memory. Eur Neuropsychopharmacol 27:900-912. CrossRef Medline

Lorrain DS, Baccei CS, Bristow LJ, Anderson JJ, Varney MA (2003) Effects of ketamine and $\mathrm{N}$-methyl-D-aspartate on glutamate and dopamine release in the rat prefrontal cortex: modulation by a group II selective metabotropic glutamate receptor agonist LY379268. Neuroscience 117:697-706. Medline

Magnusson KR, Bai L, Zhao X (2005) The effects of aging on different C-terminal splice forms of the zeta1(NR1) subunit of the N-methyld-aspartate receptor in mice. Brain Res Mol Brain Res 135:141149. CrossRef Medline

Maksymetz J, Moran SP, Conn PJ (2017) Targeting metabotropic glutamate receptors for novel treatments of schizophrenia. Mol Brain 10:15. CrossRef Medline

Mannaioni G, Marino MJ, Valenti O, Traynelis SF, Conn PJ (2001) Metabotropic glutamate receptors 1 and 5 differentially regulate CA1 pyramidal cell function. J Neurosci 21:5925-5934. Medline

Matosin N, Frank E, Deng C, Huang X-F, Newell KA (2013) Metabotropic glutamate receptor 5 binding and protein expression in schizophrenia and following antipsychotic drug treatment. Schizophr Res 146:170-176. CrossRef Medline

McOmish CE, Pavey G, Gibbons A, Hopper S, Udawela M, Scarr E, Dean B (2016) Lower [3H]LY341495 binding to mGlu2/3 receptors in the anterior cingulate of subjects with major depressive disorder but not bipolar disorder or schizophrenia. J Affect Disord 190:241248. CrossRef Medline

McQuail JA, Bañuelos C, LaSarge CL, Nicolle MM, Bizon JL (2012) $\mathrm{GABA}(\mathrm{B})$ receptor GTP-binding is decreased in the prefrontal cortex but not the hippocampus of aged rats. Neurobiol Aging 33: 1124.e1-e12. CrossRef Medline

McQuail JA, Davis KN, Miller F, Hampson RE, Deadwyler SA, Howlett AC, Nicolle MM (2013) Hippocampal $\mathrm{G} \alpha \mathrm{q} / 11$ but not $\mathrm{G} \alpha \mathrm{O}$-coupled receptors are altered in aging. Neuropharmacology 70:63-73. CrossRef Medline

McQuail JA, Beas BS, Kelly KB, Simpson KL, Frazier CJ, Setlow B, Bizon JL (2016) NR2A-containing NMDARs in the pCortex are required for working memory and associated with age-related cognitive decline. J Neurosci 36:12537-12548. CrossRef

Mitchell JJ, Anderson KJ (1998) Age-related changes in [3H]MK-801 binding in the Fischer 344 rat brain. Neurobiol Aging 19:259-265. Medline

Moghaddam B, Adams BW (1998) Reversal of phencyclidine effects by a group II metabotropic glutamate receptor agonist in rats. Science 281:1349-1352. Medline

Moghaddam B, Javitt D (2012) From revolution to evolution: the glutamate hypothesis of schizophrenia and its implication for treatment. Neuropsychopharmacology 37:4-15. CrossRef Medline

Moghaddam B, Adams B, Verma A, Daly D (1997) Activation of glutamatergic neurotransmission by ketamine: a novel step in the pathway from NMDA receptor blockade to dopaminergic and cognitive disruptions associated with the prefrontal cortex. J Neurosci 17:2921-2927. Medline

Muly EC, Mania I, Guo J-D, Rainnie DG (2007) Group II metabotropic glutamate receptors in anxiety circuitry: correspondence of physiological response and subcellular distribution. J Comp Neur 505: 682-700. CrossRef Medline 
Niswender CM, Conn PJ (2010) Metabotropic glutamate receptors: physiology, pharmacology, and disease. Annu Rev Pharmacol Toxicol 50:295-322. CrossRef Medline

Niswender CM, Jones CK, Lin X, Bubser M, Thompson Gray A, Blobaum AL, Engers DW, Rodriguez AL, Loch MT, Daniels JS, Lindsley CW, Hopkins CR, Javitch JA, Conn PJ (2016) Development and antiparkinsonian activity of VU0418506, a selective positive allosteric modulator of metabotropic glutamate receptor 4 homomers without activity at mGlu2/4 heteromers. ACS Chem Neurosci 7:1201-1211. CrossRef Medline

Novitskaya YA, Dravolina OA, Zvartau EE, Danysz W, Bespalov AY (2010) Interaction of blockers of ionotropic NMDA receptors and metabotropic glutamate receptors in a working memory test in rats. Neurosci Behav Physiol 40:807-811. CrossRef

Okamoto N, Hori S, Akazawa C, Hayashi Y, Shigemoto R, Mizuno N, Nakanishi S (1994) Molecular characterization of a new metabotropic glutamate receptor mGluR7 coupled to inhibitory cyclic AMP signal transduction. J Biol Chem 269:1231-1236. Medline

Oscar-Berman M, Bonner RT (1985) Matching- and delayed matching-to-sample performance as measures of visual processing, selective attention, and memory in aging and alcoholic individuals. Neuropsychologia 23:639-651. Medline

Panizzutti R, Scoriels L, Avellar M (2014) The co-agonist site of NMDA-glutamate receptors: a novel therapeutic target for agerelated cognitive decline. Curr Pharm Des 20:5160-5168. Medline

Patil ST, Zhang L, Martenyi F, Lowe SL, Jackson KA, Andreev BV, Avedisova AS, Bardenstein LM, Gurovich IY, Morozova MA, Mosolov SN, Neznanov NG, Reznik AM, Smulevich AB, Tochilov VA, Johnson BG, Monn JA, Schoepp DD (2007) Activation of mGlu2/3 receptors as a new approach to treat schizophrenia: a randomized phase 2 clinical trial. Nat Med 13:1102-1107. CrossRef Medline

Paxinos G, Watson C (2005) The rat brain in stereotaxic coordinates. San Diego: Elsevier Academic Press.

Piggott MA, Perry EK, Perry RH, Court JA (1992) [3H]MK-801 binding to the NMDA receptor complex, and its modulation in human frontal cortex during development and aging. Brain Res 588:277286. Medline

Ramos BP, Stark D, Verduzco L, van Dyck CH, Arnsten AFT (2006) $\alpha 2 \mathrm{~A}$-adrenoceptor stimulation improves prefrontal cortical regulation of behavior through inhibition of CAMP signaling in aging animals. Learn Mem 13:770-776. CrossRef

Rapp PR, Amaral DG (1989) Evidence for task-dependent memory dysfunction in the aged monkey. J Neurosci 9:3568-3576. Medline

Sansig G, Bushell TJ, Clarke VR, Rozov A, Burnashev N, Portet C, Gasparini F, Schmutz M, Klebs K, Shigemoto R, Flor PJ, Kuhn R, Knoepfel T, Schroeder M, Hampson DR, Collett VJ, Zhang C, Duvoisin RM, Collingridge GL, van Der Putten H (2001) Increased seizure susceptibility in mice lacking metabotropic glutamate receptor 7. J Neurosci 21:8734-8745. CrossRef

Seamans JK, Floresco SB, Phillips AG (1995) Functional differences between the prelimbic and anterior cingulate regions of the rat prefrontal cortex. Behav Neurosci 109:1063-1073. Medline

Sidiropoulou K, Lu F-M, Fowler MA, Xiao R, Phillips C, Ozkan ED, Zhu MX, White FJ, Cooper DC (2009) Dopamine modulates an mGluR5-mediated depolarization underlying prefrontal persistent activity. Nat Neurosci 12:190-199. CrossRef Medline
Sierra-Mercado D, Padilla-Coreano N, Quirk GJ (2011) Dissociable roles of prelimbic and infralimbic cortices, ventral hippocampus, and basolateral amygdala in the expression and extinction of conditioned fear. Neuropsychopharmacology 36:529-538. CrossRef

Sloan HL, Good M, Dunnett SB (2006) Double dissociation between hippocampal and prefrontal lesions on an operant delayed matching task and a water maze reference memory task. Behav Brain Res 171:116-126. CrossRef

Storey JD, Tibshirani R (2003) Statistical significance for genomewide studies. Proc Natl Acad Sci USA 100:9440-9445. CrossRef Medline

Tanabe Y, Masu M, Ishii T, Shigemoto R, Nakanishi S (1992) A family of metabotropic glutamate receptors. Neuron 8:169-179. Medline

Tanabe Y, Nomura A, Masu M, Shigemoto R, Mizuno N, Nakanishi S (1993) Signal transduction, pharmacological properties, and expression patterns of two rat metabotropic glutamate receptors, mGluR3 and mGluR4. J Neurosci 13:1372-1378. CrossRef

Timmer KM, Steketee JD (2012) Examination of a role for metabotropic glutamate receptor 5 in the medial prefrontal cortex in cocaine sensitization in rats. Psychopharmacology (Berl) 221:91100. CrossRef Medline

Tyszkiewicz JP, Gu Z, Wang X, Cai X, Yan Z (2004) Group II metabotropic glutamate receptors enhance NMDA receptor currents via a protein kinase C-dependent mechanism in pyramidal neurones of rat prefrontal cortex. J Physiol 554:765-777. CrossRef

Vertes RP (2004) Differential projections of the infralimbic and prelimbic cortex in the rat. Synapse 51:32-58. CrossRef Medline

Vertes RP (2006) Interactions among the medial prefrontal cortex, hippocampus and midline thalamus in emotional and cognitive processing in the rat. Neuroscience 142:1-20. CrossRef Medline

Vinson PN, Conn PJ (2012) Metabotropic glutamate receptors as therapeutic targets for schizophrenia. Neuropharmacology 62: 1461-1472. CrossRef Medline

Walker DL, Rattiner LM, Davis M (2002) Group II metabotropic glutamate receptors within the amygdala regulate fear as assessed with potentiated startle in rats. Behav Neurosci 116:10751083. Medline

Wang M, Ramos BP, Paspalas CD, Shu Y, Simen A, Duque A, Vijayraghavan S, Brennan A, Dudley A, Nou E, Mazer JA, McCormick DA, Arnsten AFT (2007) $\alpha 2$ A-adrenoceptors strengthen working memory networks by inhibiting CAMP-HCN channel signaling in prefrontal cortex. Cell 129:397-410. CrossRef

Wang M, Yang Y, Wang C-J, Gamo NJ, Jin LE, Mazer JA, Morrison $\mathrm{JH}$, Wang X-J, Arnsten AFT (2013) NMDA receptors subserve persistent neuronal firing during working memory in dorsolateral prefrontal cortex. Neuron 77:736-749. CrossRef

Woźniak M, Acher F, Marciniak M, Lason'-Tyburkiewicz M, Gruca P, Papp M, Pilc A, Wierońska JM (2016) Involvement of GABAB receptor signaling in antipsychotic-like action of the novel orthosteric agonist of the mGlu4 receptor, LSP4-2022. Curr Neuropharmacol 14:413-426. CrossRef

Xi Z-X, Baker DA, Shen H, Carson DS, Kalivas PW (2002) Group II metabotropic glutamate receptors modulate extracellular glutamate in the nucleus accumbens. J Pharmacol Exp Ther 300:162171. Medline 